\title{
Efectos de los RNAm maternos sobre la maduración del ovocito y el desarrollo embrionario temprano en mamíferos. Revisión
}

\author{
Effects of the maternal mRNA on the maturation of the \\ oocyte and early embryonic development in mammals. \\ Review
}

\author{
M. Eduviges Burrola-Barrazaa, Everardo González-Rodrígueza
}

\begin{abstract}
RESUMEN
Obtener ovocitos madurados in vitro, que sean competentes para fertilizarse y originar un porcentaje superior al $50 \%$ de blastocitos viables, es una de las principales metas que existen en el desarrollo in vitro de embriones bovinos. Es por ello necesario entender los procesos celulares, que desembocan en la maduración del ovocito durante la foliculogénesis y su subsecuente transición al embrión. La transición del ovocito al embrión es un proceso complejo que involucra la inactivación genómica del ovocito y la activación del genoma embrionario. Este proceso se da en bovinos en la etapa de 8 a 16 células y presenta una degradación selectiva de RNAm maternos, que fueron almacenados durante la ovogénesis y son la fuente para la codificación de proteínas en las etapas iníciales del desarrollo embrionario. La acción de los RNAm maternos es clave para que la activación del genoma embrionario se realice en tiempo y forma adecuados. Entender la participación de estos transcritos en la activación del genoma embrionario, es esencial para esclarecer los procesos celulares que fallan en los protocolos de maduración de ovocitos in vitro. Es por esto que el objetivo de esta revisión fue recopilar la información de los principales RNAm maternos que han sido identificados tanto en el modelo murino como el bovino, esto con el fin de integrar el conocimiento relacionado con los procesos genómicos que permiten el desarrollo del embrión en el bovino, y diseñar nuevas estrategias que permitan mejorar los protocolos de fertilización in vitro.
\end{abstract}

PALABRAS CLAVE: Ovocito, Activación genoma embrionario, Bovino.

\begin{abstract}
Get in vitro matured oocytes that could be competent for in vitro fertilization with a result of $50 \%$ viable blastocysts, is one of the main problems in the in vitro development of bovine embryos. For these reason, is necessary to understand the cellular processes that lead to the maturation of the oocyte during folliculogenesis and subsequent transition to the embryo. The transition from oocyte to embryo is a complex process that involves genomic inactivation of the oocyte and embryonic genome activation. This process occurs in cattle in the stage of 8 to 16 cells where there are a selective degradation of maternal mRNA, which were stored during oogenesis and are the source of protein in the early stages of embryonic development. The action of maternal mRNA is a key for that embryonic genome activation takes place in form and time. Understanding the involvement of these transcripts in embryonic genome activation is essential to elucidate the cellular processes falling in oocyte maturation in vitro protocols. The aim of this review was to gather information from maternal genes that have been isolated both in the murine model and cattle, this in order to incorporate knowledge related to genomic processes that enable the development of the embryo in cattle, and to design also new strategies to improve in vitro fertilization protocols.
\end{abstract}

KEY WORDS: Oocytes, Embryonic genome activation, Bovine.

Recibido el 29 de mayo de 2012. Aceptado el 10 octubre de 2012.

a Facultad de Zootecnia y Ecología, Universidad Autónoma de Chihuahua. Perif. R. Aldama km. 1, 31453 Chihuahua, Chih. México. Teléfono 01(614)4340303, ext. 115. mburrola1@uach.mx Correspondencia al primer autor. 


\section{INTRODUCCIÓN}

En el campo de la reproducción animal, la identificación y caracterización de los genes que participaran en la regulación del crecimiento del ovocito y de la transición del ovocito al embrión, son requeridos para entender los mecanismos de maduración, fertilización y desarrollo embrionario de animales domésticos como el bovino(1-3). El desarrollo potencial de un embrión depende del ovocito del cual se originó; por lo tanto el proceso de maduración por medio del cual el ovocito adquiere competencia, es crítico para generar embriones eficientes que originen individuos sanos después de ser implantados(4). En los animales domésticos como el bovino, uno de los principales problemas a los que se enfrenta la fertilización in vitro es el bajo porcentaje de blastocistos viables obtenidos a partir de ovocitos madurados in vitro(5,6). De acuerdo a la experiencia de diversos grupos de investigación(7-9), en los sistemas bovinos, del total de ovocitos que se someten a maduración in vitro (IVM) sólo se logra obtener aproximadamente un $40 \%$ de blastocistos viables; lo que es muy diferente a lo observado a partir de ovocitos madurados in vivo, donde el porcentaje de blastocistos viables obtenidos es cercano al $80 \%$. Esto sugiere que la IVM modifica el microambiente del ovocito, al ocasionar un cambio celular y genético que impide que esta célula se desarrolle de manera normal(10). Desde folículo primordial hasta el folículo preantral, el ovocito almacena transcritos(11), cuya traducción genera proteínas que son claves para su maduración(12) y, después de ser fertilizado, para su transición hacia el embrión(13).

Dado que estos RNAm se transcriben en el ovocito y permanecen hasta las primeras etapas de la embriogénesis, son denominados RNAm maternos(14). La mayoría de los genes que codifican para este tipo de RNAm, han sido descritos en ratones (Cuadro 1 ) y pocos se han descrito en el bovino (Cuadro 2). Esclarecer el perfil de genes maternos que participan en la

\section{INTRODUCTION}

In the field of animal reproduction, the identification and characterization of genes that participate in the regulation of the oocyte growth and the transition of the oocyte to embryo, are required to understand the mechanisms of maturation, fertilization and embryonic development of domestic animals such as the bovine(1-3). The potential development of an embryo depends on the oocyte, from which it originated; therefore the mature process by means the oocyte acquires competition, is critical to generate efficient embryos that originate healthy individuals after being implanted(4). In domestic animals like cattle, one of the main problems faced by in vitro fertilization is the low percentage of viable blastocysts derived from in vitro matured oocytes $(5,6)$. According to the experience of different research groups $(7-9)$ in cattle systems, the total number of oocytes undergoing in vitro maturation (IVM) only manages to get about $40 \%$ of the viable blastocysts; versus in vivo matured oocytes, where the percentage of viable blastocysts obtained is close to $80 \%$. This suggests that the IVM modifies the microenvironment of the oocyte, to cause cellular and genetic change that prevents this cell to develop as normal(10). From primordial follicle until the preantral follicle the oocyte stores transcripts(11), whose translation produces proteins that are key to its maturation(12) and, after being fertilized, for its transition to the embryo(13).

Since these mRNA are transcribed in the oocyte and remain until the early stages of embryogenesis, they are called maternal mRNA(14). Most of the genes encoding for this type of mRNA, have been described in mice (Table 1), and few have been described in the bovine (Table 2). Clarify the profile of maternal genes involved in competition and early embryogenesis in the cattle, is necessary to improve the culture conditions on IVM of oocytes that raise the success rate of blastocysts, that originate a healthy animal when be implanted. This is why the objective of this review is to show the known details of the major maternal 
EFECTOS DE LOS RNAm MATERNOS SOBRE LA MADURACION DEL OVOCITO Y EL DESARROLLO EMBRIONARIO

Cuadro 1. Genes con efecto materno identificados en el modelo murino

Table 1. Genes with maternal effect identified in the murine model

\begin{tabular}{|c|c|c|c|}
\hline Effect & Function & Maternal mRNA & References \\
\hline Oocyte maturation & Adding adenines to UTR'3 of mRNA & epab & 42 \\
\hline Epigenesis regulation & Repair and modification of histones & hr6a & 78 \\
\hline Chromatine remodelation & $\operatorname{brg} 1$ & 108 & \\
\hline Decondensation of sperm DNA & npm2 & 80,104 & \\
\hline \multirow[t]{7}{*}{ DNA methylation } & gse & 90,91 & \\
\hline & trim28 & 97 & \\
\hline & tet3 & 89 & \\
\hline & dnmt1o & 99,100 & \\
\hline & dnmta-dnmt/3 & 72,74 & \\
\hline & stella & $92-96$ & \\
\hline & $z f p 57$ & 10 & \\
\hline \multirow[t]{5}{*}{ Genome embryo activation } & Transcription factor & hsf1 & 109,110 \\
\hline & & bnc1 & 111 \\
\hline & & ctcf & 112 \\
\hline & & oct -4 & 113 \\
\hline & & sox2 & 116 \\
\hline \multirow[t]{4}{*}{ Degradation of mRNA maternal } & Processing of microRNAs & dicer & $46,47,60$ \\
\hline & & ago-2 & 51 \\
\hline & Union to AU elements in UTR'3 & zfp3612 & 118 \\
\hline & Degradation for autophagy & $\operatorname{atg} 5$ & 119 \\
\hline \multirow[t]{6}{*}{ Preimplantation } & Syngamy participation & zar-1 & 124,127 \\
\hline & Progression from zigoto to 2 -cell embryo & mater & 131 \\
\hline & & floped & 10 \\
\hline & & tle6 & 10 \\
\hline & & filia & 132 \\
\hline & & padi6 & 133 \\
\hline
\end{tabular}

competencia y embriogénesis temprana en el bovino, es algo necesario para mejorar las condiciones de cultivo en IVM de ovocitos que eleven el porcentaje de éxito de blastocistos, que al ser implantados originen un animal sano. Es por esto que el objetivo de la presente revisión es mostrar la información conocida de los principales RNAm maternos que han sido identificados tanto en el modelo murino como el bovino, esto con el fin de integrar el conocimiento relacionado con los procesos genómicos que permiten el desarrollo del
mRNA that have been identified, both in the murine as the cattle models, in order to integrate the knowledge related to genomic processes that allow the development of the embryo in cattle, and design new strategies that improve in vitro fertilization (IVF) protocols.

\section{EFFECT OF MATERNAL GENES ON THE} MATURATION OF THE OOCYTE

The oogenesis is the process by which an egg grows and matures, and is concomitant with 
Cuadro 2. Genes con efecto materno identificados en el bovino

Table 2. Genes with maternal effect identified in bovines

\begin{tabular}{llcc}
\hline Effect & Function & Maternal mRNA & References \\
\hline Epigenesis regulation & sperm DNA decondensation & NPM2 & 80,104 \\
& DNA methylation & DMT1 & 150 \\
Genome embryo activation & Transcription factor & NOBOX & 148 \\
& Granulosa cells regulation & JY-1 & 146,147 \\
& Nuclear proteins transporter & KPNA7 & 145 \\
Degradation of mRNA maternal & Processing of microRNAs & DICER & 148 \\
& & DROSHA & 141 \\
Preimplantation & Syngamy participation & ZAR-1 & 129 \\
& Progression from zigoto to 2-cell embryo & MATER & 142 \\
\hline
\end{tabular}

embrión en el bovino, y diseñar nuevas estrategias que permitan mejorar los protocolos de fertilización in vitro (FIV).

\section{EFECTO DE LOS GENES MATERNOS SOBRE LA MADURACIÓN DEL OVOCITO}

La ovogénesis es el proceso por el cual un ovocito crece y madura, y sucede de forma concomitante con la foliculogénesis, que es el proceso por medio del cual se desarrolla un folículo ovárico(15). Ambas etapas se inician en la vida fetal; para ello las células germinales primordiales del saco vitelino migran hacia las gónadas en formación. Una vez ahí, las células germinales primordiales se multiplican por mitosis y forman grupos de ovogonias conectadas entre sí por interacciones citoplásmicas, que al asociarse con células pregranulosas planas dan origen a los folículos primordiales(16). Los ovarios neonatos de la mayoría de los mamíferos, están poblados por este tipo de folículos en un rango de 100,000 a 400,000 folículos/hembra(17). Cada folículo primordial consta de un ovocito primario detenido en la profase de meoisis I en la etapa de diploteno, que se rodea de una capa sencilla de células pregranulosas(18). Durante el transcurso de la vida reproductiva de la hembra, un cohorte de folículos primordiales son the folliculogenesis, process by which an ovarian follicle develops(15). Both stages are started in fetal life; for this, primordial germ cells of the yolk sac migrate into the gonads in formation. Once there, the primordial germinal cells multiply by mitosis and form groups of oogonia connected by cytoplasmic interactions, that by partnering with layer of pre-granulose cells give rise to the primordial follicles(16). The neonatal ovaries of most mammals, are populated by this type of follicles in a range from 100,000 to 400,000 follicles/female(17). Each primordial follicle consists of a primary oocyte arrested in prophase of meiosis I in the diplotene stage, which is surrounded by a single layer of pregranulose cells(18). During the course of the reproductive life of the female, a cohort of primordial follicles are recruited continuously and cyclically from the set of primordial follicles in resting to grow and differentiate themselves(15), of these, more than $99.9 \%$ are not used due to atresia $(15,19)$. The start of the folliculogenesis is characterized by the transition of flat pregranulosa cells to cuboidal granulosa, giving rise to the primary follicle. At this point, a transformation of epithelioid stromal cells that surround the follicle is given to and teak cells are generated(15). These cells are separated from the granulosa cells by a basement 
reclutados continua y cíclicamente a partir del conjunto de folículos primordiales en reposo para crecer y diferenciarse(15), de estos, más del $99.9 \%$ no son utilizados debido a la atresia(15,19). El inicio de la foliculogénesis se caracteriza por la transición de células pregranulosa planas a cuboidales de la granulosa, que dan lugar al folículo primario. En este punto, se da una transformación epiteloide de las células estromales que rodean al folículo y se generan las células de la teca(15). Estas células quedan separadas de las células granulosas por una membrana basal y es en este espacio donde se forman capilares sanguíneos y linfáticos(20). En este momento, las células de la granulosa proliferan y se arreglan en múltiples capas concéntricas alrededor del ovocito, el cual comienza a aumentar de tamaño, dando así lugar al folículo secundario. En esta fase, el ovocito inicia la síntesis de la zona pelúcida, que es una capa extracelular de glicoproteínas conformadas por ZP1, ZP2 y ZP3(21). Hasta aquí comprende la fase preantral que dura aproximadamente el $85 \%$ del tiempo total de la foliculogénesis(15).

A medida que proliferan las células foliculares y el ovocito alcanza mayor tamaño, entre las capas de las células de la granulosa se forma un espacio lleno de líquido denominado antro, el cual contiene una mezcla compleja de proteínas, hormonas y iones(22). Aquí comienza la fase antral, conformada por la presencia del folículo terciario o de $\operatorname{Graaf}(4)$, donde los ovocitos alcanzan un mayor tamaño y las células granulosas se diferencian en dos subpoblaciones: células cumulares y células murales. Las células murales que se localizan en capas por debajo de la membrana basal, recubren la pared interna del folículo y se encargan de llevar a cabo las funciones endocrinas, incluida la esteroidogénesis(15). Las células cumulares que rodean al ovocito, forman el complejo cúmulos-ovocito (COC), donde a través de una comunicación bidireccional promueven el crecimiento y la maduración del ovocito(23). Dentro del COC, el ovocito arrestado en la profase de la meiosis I es estimulado por membrane and it is in this space where blood capillaries and lymph are formed(20). At this time, the granulosa cells proliferate and are arranged in multiple concentric layers around the oocyte, which begins to increase in size, thus giving rise to the secondary follicle. In this phase, the oocyte initiates the synthesis of the zona pellucida, which is an extracellular layer of glycoproteins formed by ZP1, ZP2 and ZP3(21). So far, it includes the preantral stage that last approximately $85 \%$ of the total time of the folliculogenesis(15).

As follicular cells proliferate, and oocyte reaches larger between layers of granulosa cells a liquidfilled space called antrum is formed, which contains a complex mixture of proteins, hormones and ions(22). Here begins the antral stage, formed by the presence of the tertiary or Graafian follicle(4), where the oocytes reach a larger size and the granulosa cells differentiate into two subpopulations: cumulus cells and cell wall. Cells wall that are located in layers below the basal membrane lining the inner wall of the follicle are responsible for carrying out the endocrine functions, including steroidogenesis(15). Cumulus cells that surround the oocyte, form the cumulus-oocyte complex (COC), which through a bidirectional communication promote the growth and maturation of the oocyte(23). Within the $\mathrm{COC}$, the oocyte arrested in prophase of meiosis $\mathrm{I}$ is stimulated by the luteinizing hormone (LH) resumes meiosis, releases the first polar body, and here is where the first meiotic division takes place, and progresses to metaphase II(4), where again halts its progress; at that point is already considered a mature and competent oocyte to be fertilized(24). In cattle, display of meiotic competence does not occur until the antral follicle stage, when the oocyte diameter is greater than $100 \mu \mathrm{m}(4)$.

\section{Inactivation / Activation of maternal $m R N A$} Throughout the process of folliculogenesisoogenesis, from the primary follicle to the antral follicle, the oocyte is in constant growth, which 
la hormona luteinizante (LH), por lo que reanuda la meiosis, se libera el primer cuerpo polar, y es aquí donde sucede la primera división meiótica, y progresa a metafase $\mathrm{II}^{(4)}$, donde de nuevo detiene su desarrollo; en ese punto se considera ya un ovocito maduro y competente para ser fertilizado(24). En bovinos, la exhibición de competencia meiótica no ocurre hasta la etapa de folículo antral, cuando el diámetro del ovocito es mayor que $100 \mu \mathrm{m}(4)$.

\section{Inactivación/Activación de los RNAm maternos}

Durante todo el proceso de foliculogénesisovogénesis, desde el folículo primario hasta el folículo antral, el ovocito se encuentra en constante crecimiento, lo cual es evidente por un incremento en los procesos de transcripción y traducción(4). Durante la etapa de crecimiento, el ovocito transcribe RNAm que almacena de forma inactiva, es decir sin ser traducidos, y que utilizará durante su maduración hacia metafase II y una vez que ha sido fecundado, durante la transición del ovocito al embrión(14). A este tipo de RNAm se les denomina RNAm con efecto materno $(25,26)$ y es en el ratón, el mamífero en el cual más se han estudiado (Cuadro 1). Las características principales de este tipo de transcritos radica en que, además de provenir del proceso de transcripción de los ovocitos, son activados durante el proceso de maduración del ovocito, para servir como aporte proteico en ese proceso y en la etapa inicial de la embriogenesis(14) y deben ser degradados a la par que se activa el genoma embrionario, para evitar un arresto en las etapas tempranas del desarrollo del embrion(11).

En mamíferos como el ratón, durante la maduración meiótica, aproximadamente $12 \mathrm{~h}$ antes de la ovulación, la transcripción en el ovocito comienza a ser inactiva; en este momento el único soporte de proteínas proviene de los RNAm almacenados en las etapas iniciales de la ovogénesis, y muchos de los RNAm almacenados comienzan a activarse y a ser traducidos(25). En organismos como Xenopus y is evident by an increase in the processes of transcription and translation(4). During the growth stage, the oocyte transcribes mRNA storing in inactive form, ie without being translated, and used during their maturation to metaphase II, and once it has been fertilized, during the transition from oocyte to embryo(14). This type of mRNA are called mRNA with maternal effects $(25,26)$, and the mouse is the mammal in which most have been studied (Table 1 ). The main features of such transcripts is that, in addition to stem from the process of transcription of oocytes, they are activated during the process of maturation of the oocyte, to serve as protein intake in the process and in the initial stage of embryogenesis(14) and must be degraded at the same time embryonic genome is activated to avoid arrest in the early stages of embryo development(11).

In mammals such as mice, during meiotic maturation, approximately $12 \mathrm{~h}$ before ovulation, the oocyte transcription starts to become inactive; at this time the only support comes from the mRNA proteins stored in the initial stages of oogenesis, and many of the stored mRNA start activation and be translated(25). In organisms such as Xenopus and Drosophila, it is well established that during oogenesis there is a regulated process that maintains the inactive mRNA during active growth stage and when the egg begins to mature(27-30). In both, model mouse(31) and Xenopus(32), in addition to the polyadenylation signal (5'AAUAAA'3) located in the region not translated ' 3 (UTR' 3 ) of the mRNA, is present the sequence consensus (5'UUUUUAU' 3 ) called cytoplasmic polyadenylation element (CPE), which is recognized by the protein union to $C P E$ (PCEB). In Xenopus, the inactive state of the maternal mRNA is mediated by the PCEB protein which interacts at the same time both with the CPE box in the extreme $3^{\prime}$ UTR of the maternal mRNA, and the initiation of translation 4E (eIF4E), that failure to join the initiation of translation 4F complex (eIF4F) inhibits the translation; on the other hand, the PCEB/PCE interaction causes the complex protein CCR4/ 
Drosophila, está bien demostrado que durante la ovogénesis existe un proceso regulado que mantiene a los RNAm inactivos durante la etapa de crecimiento y activos cuando el ovocito empieza a madurar(27-30). Tanto en el modelo de ratón(31) como de Xenopus(32), además de la señal de poliadenilación (5'AAUAAA'3) ubicada en la región no traducida '3 (UTR'3) del RNAm, está presente la secuencia consenso (5'UUUUUAU'3) denominada elemento de poliadenilación citoplásmica (CPE), la cual es reconocida por la proteína de unión a CPE (CPEB). En Xenopus el estado inactivo de los RNAm maternos está mediado por la proteína CPEB, que interacciona al mismo tiempo tanto con la caja CPE en el extremo 3 'UTR del RNAm materno, como al factor de inicio de la traducción 4E (eIF4E), que al no unirse al complejo de inicio de la traducción 4F (eIF4F) inhibe la traducción; por otro lado, la interacción CPEB/CPE ocasiona que el complejo proteico CCR4/NOT empiece a degradar la cola de poliadeninas(29). Una vez que la meiosis se reactiva y el proceso de maduración del ovocito inicia, la activación de los RNAm maternos se da a través del proceso de poliadenilación citoplásmica(33). Durante la maduración meiótica, la cinasa aurora (Eg2) fosforila la CPEB; de esta forma fosforilada CPEB se une a la proteína Maskin, por lo que se libera eIF4E, el cual puede ir y conformar el complejo eIF4F, dando lugar a la traducción(34). En ovocitos bovinos y porcinos, la unión de eIF4E al complejo eIF4F se relaciona con un aumento en la fosforilación de eIF4E y es un indicativo de que el ovocito está en metafase II $(35,36)$. Además, este proceso promueve la unión del factor específico de la poliadenilación citoplásmica (CPSF) con la secuencia 5'AAUAAA'3; que a su vez permite que la proteína embrionaria de unión de adeninas (ePAB) adicione adeninas al UTR'3, lo que provoca que el UTR'5 se estabilice para la correcta traducción del RNAm(37-41). En ratón la expresión de ePAB se presenta en la profase I y metafase II de ovocitos y en embriones de 2 a 4 células, ya que se activa el genoma embrionario; esta expresión es suprimida, y debido a esto es considerada un RNAm materno(42).
NOT start to degrade the tail of polyadenine(29). Once meiosis is reactivated and oocyte the maturation process begin, the maternal mRNA activation occurs through the process of cytoplasmic polyadenylation(33). During meiotic maturation, the Aurora kinase (Eg2) phosphorylates the PCEB; in this way phosphorylated PCEB joins Maskin protein, so it releases eIF4E, which can go and create the eIF4F complex, giving rise to the translation(34). In cattle and swine oocytes, the union of eIF4E to the complex eIF4F is related to an increase in eIF4E phosphorylation and is an indicative that the oocyte is at metaphase $\operatorname{II}(35,36)$. In addition, this process promotes the union of the specific factor of cytoplasmic polyadenylation (CPSF) with the sequence 5'AAUAAA' 3 ; at the same time allowing the embryonic protein of binding adenine (ePAB) to add adenine to the UTR' 3 , which causes the UTR' 5 to stabilize for the correct translation of the mRNA(37-41). In mouse ePAB expression occurs in prophase I and metaphase II oocytes and embryos from 2-4 cells, since it activates the embryonic genome; this expression is suppressed, and due to this is considered a maternal mRNA(42).

Role of the Small RNAs during the oogenesis As its name suggests the small RNAs, are small oligonucleotides with an approximate length of 18 to 24 bases, which hybridize with the 3'UTR of an mRNA to promote its degradation(43). In Zebrafish oocytes $(44,45)$, mouse $(46,47)$ and bovine $(48)$, small RNAs known as microRNAs (miRNAs) and the small RNAs of endogenous interference (endo-siRNAs).

The miRNAs are encoded within the intragenic regions(49) and within intronic regions(50). Those encoded in intragenic regions are expressed under the action of RNApol II and referred to as pri-miRNAs (primary miRNA); these are processed by a complex of ribonucleic protein, the enzyme DROSHA and protein DGCR8 that cut to the pri-miRNA and leave it in structure of stem-bubble(51,52). The miRNAs that are encoded in intronic regions are expressed 
Papel de los RNAs pequeños durante la ovogénesis

Como su nombre lo indica los RNAs pequeños, son pequeños oligonucleótidos con una longitud aproximada de 18 a 24 bases, que hibridan con el 3'UTR de un RNAm para promover su degradación(43). En los ovocitos de Zebrafish $(44,45)$, ratón $(46,47)$ y bovino $(48)$, abundan RNAs pequeños, conocidos como microRNAs (miRNAs) y los RNAs pequeños de interferencia endógena (endo-siRNAs).

Los miRNAs están codificados dentro de regiones intergénicas(49) y dentro de regiones intrónicas(50). Los que están codificados en regiones intergénicas se expresan bajo la acción de la RNApol II y se denominan pri-miRNAs (miRNA primario), estos son procesados por un complejo ribonucleico proteico, compuesto por la enzima DROSHA y la proteína DGCR8 que cortan al pri-miRNA y lo dejan en estructura de tallo burbuja $(51,52)$. Los miRNAs que se encuentran codificados en regiones intrónicas se expresan de acuerdo al gen donde se encuentren, formando lo que se conoce como Mirtron y son liberados durante el empalme de exones en forma de tallo burbuja(53). Sea cual sea la vía de procesamiento del tallo-burbuja, el resultado es el mismo, un precursor de miRNA (pre-miRNA) con estructura tallo-burbuja, el cual pasa al citoplasma a través de la proteína EXPORTINA5, donde es cortado por DICER, una RNasa III, para obtener 2 miRNAs de aproximadamente $20 \mathrm{pb}$. Una de las cadenas se selecciona para funcionar como un miRNA maduro, mientras que la otra cadena es degradada $(50,53,54)$. En ocasiones, las dos hebras de la horquilla del pre-miRNA dan lugar a dos miRNAs maduros(51). Para continuar con el procesamiento, los miRNAs son ensamblados en un complejo de ribo nucleoproteínas llamado complejo de silenciamiento inducido por miRNA (RISCs) conformado por proteínas de la familia de las Argonautas. Una vez que los miRNAs son ensamblados en el RISCs, los nucleótidos de la posición 2 al 8 en el extremo $5^{\prime}$ del miRNA participan en el reconocimiento del according to the gene where they are, forming what is known as Mirtron and are released during the splicing of exons in the form of stem-bubble(53). Whatever the way of processing of the stem-bubble, the result is the same, a precursor miRNA (pre-miRNA) with stem-bubble structure, which goes to the cytoplasm through the protein EXPORTIN5, which is cut by DICER, an RNase III, to get 2 miRNAs of approximately $20 \mathrm{pb}$. One of the chains is selected to run as a mature miRNA, while the other chain is degraded $(50,53,54)$. Occasionally, the two strands of the fork of the pre-miRNA give rise to two mature miRNAs(51). To continue with the processing, the miRNAs are assembled in a complex of ribonucleoprotein called complex of silencing induced by miRNA (RISCs) formed by proteins of the family of the Argonauts. Once the miRNAs are assembled in the RISCs, nucleotides from position 2 to 8 in the extreme $5^{\prime}$ of the miRNA are involved in recognition of the extreme 3'UTR of the RNAm target to promote that AGO proteins suppress target mRNA expression, so that, if the coupling is complete is induced endonucleolytic degradation, either, if the coupling is uneven it inhibits the translation and degradation is promoted by exonuclease(55).

The endo-siRNAs are derived from a doublestranded RNA (dsRNA), result of the hybridization of two independent RNA chains, as are the result of the expression of pseudogenes(56), transposons(57) and retrotransposons (58). Once the dsRNA is generated, it is exported to the cytosol, where is processed by the Dicer enzyme, generating multiple endo-siRNAs in sizes of 21 nucleotides that are assembled into RISCs coupled to the Ago2 $(56,59)$ and follow the same process as mentioned for the case of the miRNAs.

Murchinson et $a /(60)$ and Tang et al(46) conducted studies with mice Dicer-/- from oocytes and found that these gametes suffered a meiotic arrest due to a defect in the mitotic spindle, which caused a total disruption of chromosomes at the equator of the cell. The 
extremo 3'UTR del RNAm blanco para promover que las proteínas AGO repriman la expresión del RNAm blanco, de forma tal que, si el acoplamiento es completo se induce una degradación endonucleótica, o bien, si el acoplamiento es desigual se inhibe la traducción y se promueve una degradación por exonucleasas(55).

Los endo-siRNAs se derivan de un RNA de doble cadena (dsRNA) resultado de la hibridación de dos cadenas independientes de RNA, lo cuales son el resultado de la expresión de pseudogenes(56), transposones(57) y retrotransposones(58). Una vez que se genera la dsRNA, ésta es exportada al citosol, donde es procesada por la enzima Dicer, generándose múltiples endo-siRNAs de tamaños de 21 nucleótidos que son ensamblados en RISCs acoplados a la Ago2 $(56,59)$ y siguen el mismo proceso que el mencionado para el caso de los miRNAs.

Murchinson et $a(60)$ y Tang et al(46) realizaron estudios con ovocitos provenientes de ratones dicer-/- y encontraron que estos gametos sufrían un arresto meiótico debido a un defecto en el huso mitótico, que provocaba una total desorganización de los cromosomas en el ecuador de la célula. En los experimentos de Tang et a(46) se demostró que hay una gran cantidad de miRNAs en el ovocito maduro, mismos que disminuyen abruptamente en el estadio embrionario de dos células; además se observó que estos embriones detenían su desarrollo y no progresaban al estadio de cuatro células. De la misma manera, Murchinson et a(60) llegan a la conclusión de que dicer es requerido para que se culmine el proceso de meiosis I y se de paso al arresto del ovocito en metafase II. Además de lo anterior, ambos autores demostraron por medio de microarreglos, que hay una sobre expresión de RNAm materno en ovocitos y embriones dicer/- $(46,60)$. Dado que dicer es quien genera tanto los miRNAs como los endo-siRNA, no quedaba claro si la maduración meiótica en el ovocito estaba relacionada con la acción de ambos RNAs pequeños o sólo por alguno de ellos. Esto quedó experiments of Tang et a/(46) showed that there are a large number of miRNAs in the mature oocyte, same that decrease sharply in the embryonic stage of two cells; also observed that these embryos stopped its development and do not progress to the stage of four cells. In the same way, Murchinson et al(60) comes to the conclusion that Dicer is required, so that the process of meiosis I is finished and is passing to the oocyte arrested in metaphase II. In addition, these authors showed, using microarrays, that there is an over expression of maternal mRNA in oocytes and embryos Dicer-/- $(46,60)$. As Dicer is who generates both the miRNAs and the endo-siRNA, it was not clear if meiotic maturation in the oocyte was related to the action of both small RNAs or only some of them. This was clarified by Suh et a(52) who showed that mice dgcr8-/- oocytes did not show any abnormality in the organization of the mitotic spindle; on the other hand when they were fertilized, the embryos showed normal development to the blastocyst stage. There were also no significant differences in the expression of maternal mRNA between oocyte dcgr8-/- and normal oocytes. Since DGRC8 is the enzyme that generates the pri-miRNA(51), their absence means that there will be no structures stem-bubble to be processed by Dicer, therefore there will be no miRNAs. These results implied that if the miRNAs are not responsible for the phenotype observed both in oocytes as in embryos dicer- $/-$, this may be a result of the effect of the endo-siRNA(52). Ma et al(47) found that the 3'UTR of the maternal transcripts over expressed in oocytes dicer-/-, had no recognition for miRNAs sequences; similarly to the microinjection, in normal oocytes immature and mature, UTR' 3 reporters with secuences target for the let-7 miRNA and miR30, there was no decrease in the reporter gene, indicating that the route of degradation by miRNA was suppressed. With all of these studies, it is clear that the miRNAs despite being present in the oocyte, do not take part in the regulation of the process of its maturation; this is intriguing since they disappear after fertilization once activated the embryonic genome(52,61). 
aclarado por Suh et a/(52) quienes demostraron que ovocitos de ratones $d g c r 8-/-$ no mostraban ninguna anomalía en la organización del huso mitótico; por el contrario cuando estos fueron fertilizados, los embriones mostraron un desarrollo normal hasta la etapa de blastocisto. Además no hubo diferencias significativas en la expresión de RNAm maternos entre ovocitos dcgr8-/- y ovocitos normales. Ya que DGRC8 es la enzima que genera el pri-miRNA(51), el estar ausente significa que no habrá estructuras talloburbuja para ser procesadas por DICER, por lo tanto no habrá miRNAs. Estos resultados implicaron que si los miRNAs no son los responsables del fenotipo observado tanto en ovocitos como en embriones dicer-/-, esto podría ser resultado del efecto de los endo-siRNA(52). Ma et al(47) encontraron que los 3 'UTR de los transcritos maternos sobre expresados en ovocitos dicer-/-, no presentaban secuencias de reconocimiento para miRNAs; así mismo al microinyectar, en ovocitos normales inmaduros y maduros, reporteros con UTR' 3 con secuencias blanco para los miRNA let-7 y miR30, no hubo ninguna disminución del gen reportero, lo que indicó que la vía de degradación por miRNA estaba suprimida. Con todos estos estudios es claro que los miRNAs a pesar de estar presentes en el ovocito, no forman parte en la regulación del proceso de maduración del mismo, esto es intrigante dado que desaparecen después de la fertilización una vez que se activó el genoma embrionario(52,61).

\section{EFECTO DE LOS RNAT MATERNOS SOBRE LA EMBRIOGÉNESIS TEMPRANA}

Una vez que se lleva a cabo la fecundación, el espermatozoide penetra la zona pelúcida y se fusiona con la membrana plasmática del ovocito; ya en el citoplasma el DNA del esperma, junto con el genoma del ovocito generan los pronúcleos femenino y masculino(11). Luego de $24 \mathrm{~h}$ se forma el cigoto, en el cual el DNA de cada pronúcleo empieza a ser replicado y sus cromosomas comienzan a congregarse, dando lugar así al proceso de singamia donde inicia una mitosis seguida de una citocinesis, que
EFFECT OF MATERNAL MRNA ON EARLY EMBRYOGENESIS

Once fertilization takes place, the sperm penetrates the zona pellucida and fuses with the oocyte plasma membrane; already in the cytoplasm the DNA of sperm, along with the oocyte genome, generate the female and male pronuclei(11). After $24 \mathrm{~h}$ the zygote is formed, in which the DNA of each pronucleus begins to be replicated and their chromosomes begin to congregate, thus resulting in the process of syngamy where a mitosis starts followed by a cytokinesis, generating the formation of a twocells embryo(62). Subsequently, with intervals of approximately $12 \mathrm{~h}$, occurs a second and third division, where the resulting daughtercells are morphologically identical and are called blastocyst, which are confined within the membrane of which the oocyte was. Before the next division, 8-cell embryo undergoes a cell compaction mediated by calcium, thus forming the morula stage, in which the blastocysts increase its cell-cell contact area(63). From here, cell divisions are asymmetric and give results as two different cell populations: 1) "Internal", that form the inner cell mass (ICM), which are responsible for the formation of the endoderm and mesoderm; 2) "External", composed of cells that generate the trophectoderm that is precursor of the placenta $(64,65)$.

Although the sperm provides the male genome, the onset of embryonic development depends almost entirely on its protein components, derived from the translation of maternal genes in the egg at the moment of fertilization(11). These components are used in the first divisions and are key to be given a proper activation, in space and time, of the embryonic genome, which involves their participation during the establishment of epigenetics and the embryo preimplantation(66).

\section{Maternal effect on the epigenetics}

Successful embryonic development, requires that both, paternal and maternal genome are properly expressed. In mammals, most of the 
genera la formación de un embrión de dos células(62). Posteriormente, con intervalos de aproximadamente $12 \mathrm{~h}$, ocurre una segunda y tercera división, donde las células hijas resultantes son morfológicamente idénticas y se denominan blastómeros, las cuales están confinadas dentro de la membrana de lo que fue el ovocito. Antes de la siguiente división, el embrión de ocho células se somete a una compactación celular, mediada por calcio, formándose así la mórula, en la cual los blastómeros aumentan su área de contacto célula-célula(63). A partir de aquí, las divisiones celulares son asimétricas y dan como resultado dos poblaciones celulares diferentes: 1) "Interna", compuesta por células que formarán la masa celular interna (ICM), responsables de la formación del endodermo y mesodermo; 2) "Externa", compuesta por células que generaran el trofoectodermo que es precursor de la placenta $(64,65)$.

Si bien el espermatozoide aporta el genoma masculino, el inicio del desarrollo embrionario depende casi en su totalidad de los componentes proteicos, derivados de la traducción de genes maternos presentes en el ovocito al momento de la fecundación(11). Estos componentes son utilizados en las primeras divisiones y son clave para que se dé una adecuada activación, en espacio y tiempo, del genoma embrionario, lo que involucra su participación durante el establecimiento de la epigénesis y durante la preimplantación del embrión(66).

\section{Efecto materno sobre la epigénesis}

Para que el desarrollo embrionario suceda de forma adecuada, se requiere que tanto el genoma materno como el paterno sean debidamente expresados. En los mamíferos, la mayoría de los genes son expresados en ambos alelos parentales de forma bialélica, los pocos que son transcritos de una forma monoalélica están relacionados con la epigénesis. La reprogramación epigenética se define como cualquier alteración meiótica o mitótica sobre genes are expressed in both parental alleles as bi-allelic forms, the few that are transcribed in a mono-allelic way are related to epigenetics. Epigenetic reprogramming is defined as any meiotic or mitotic alteration on DNA, which does not result in a change in their sequence, but that will have a significant impact on the development of the organism(67). During gametogenesis, both, male and female haploid genome undergoes an epigenesist process, known as genetic imprinting, consisting of methylate CpG dinucleotide sequences, what is directly related to the genetic suppression(68). The genetic imprinting occurs in regions of printing control (ICR) whose methylations settle sex specifically in the germ cells and must be retained during the embryonic development(69). About 100 imprinted genes have been identified in mammals, most are grouped and its expression is directed by ICR methylation, which are regions differentially methylated between the genome of both gametes(69-71). It is clear that the process of epigenesis is essential for proper embryonic development to take place. Within this mechanism, the maternal mRNA play a crucial role, so that the process of methylation take place in form and appropriate time(11).

Most of maternal factors involved in the regulation of embryo epigenesis have been described in the model of mouse (Table I), many of which are already well characterized with a well-defined function. DNMT3a and its cofactor DNMTL3, are maternal proteins required in the establishment of the genetic imprint in female germ cells $(72,73)$. DNMTL3 joins the residual dimethyl at lysine 4 of histone $\mathrm{H} 3$, which causes that DNMT3a methylate de novo ICRs maternal sequences. Oocytes of mouse with any of these two genes deleted, show a hypomethylation at ICR sites. These oocytes to be fertilized, generate embryos with an aberrant development showing expression of genes not methylated, whose expression is zero in the normal embryos where they are methylated; the end result of this process is the death of the embryo at embryonic d 9.5 to 10.5 with malformations related to defects in 
el DNA, que no resulta en un cambio en su secuencia, pero que tendrá un impacto significativo sobre el desarrollo del organismo(67). Durante la gametogénesis tanto el genoma haploide femenino como masculino sufre un proceso de epigénesis conocido como impronta genética (del inglés genomic imprinting) que consiste en metilar secuencias dinucleotídicas $\mathrm{CpG}$, lo que directamente se relaciona con la represión genética(68). La impronta genética se da en regiones de control de impresión (ICR) cuyas metilaciones se establecen de manera sexo específica en las células germinales y deben conservarse durante todo el desarrollo embrionario(69). Cerca de 100 genes impresos han sido identificados en los mamíferos, la mayoría se encuentran agrupados y su expresión es dirigida por la metilación ICR, las cuales son regiones diferencialmente metiladas entre el genoma de ambos gametos(69-71). Queda claro que el proceso de epigénesis es esencial para que se lleve a cabo un correcto desarrollo embrionario. Dentro de este mecanismo, los RNAm maternos juegan un papel crucial para que el proceso de metilación se realice en forma y tiempo adecuado(11).

La mayoría de los factores maternos que participan en la regulación de la epigénesis embrionaria se han descrito en el modelo del ratón (Cuadro I), muchos de los cuales están ya bien caracterizados con una función muy definida. DNMT3a y su cofactor DNMTL3, son proteínas maternas requeridas en el establecimiento de la impronta génica en células germinales femeninas $(72,73)$. DNMTL3 se une al residuo desmetilado en la lisina 4 de la histona $\mathrm{H} 3$, lo que provoca que DNMT3a metile de novo las secuencias ICRs maternas. Ovocitos de ratón con alguno de estos dos genes eliminados, muestran una hipometilación en los sitios ICR. Estos ovocitos al ser fertilizados generan embriones con un desarrollo aberrante mostrando expresión de genes no metilados, cuya expresión es nula en los embriones normales donde si están metilados, el resultado final de este proceso es la muerte del embrión en el the closure of the neural tube $(72,73)$. Before the process of fertilization, the DNA of both gametes is very compacted and hypermethylated, the male DNA is packaged in protamines, whereas the DNA of the oocyte is in histones(74). Once fertilization takes place, the membrane of the sperm fuses with the plasma membrane of the oocyte and the sperm nucleus is deposited in the cytoplasm of the oocyte(11). This point generates two pronuclei, one female and another male, where both highly specialized genomes should merge, integrate and reprogrammed to allow embryonic development and pluripotency.

After fertilization, the male genome undergoes a decondensation and is repackaged with histones present in the cytoplasm of the oocyte(75). Once both haploid genomes are packaged with histones, the DNA replication begins independently in each pronucleus. At this point in embryonic development, the transcription levels are low, being higher in the male pronucleus than the female. The histones that pack the male genome are more interacting than those found in the female pronucleus $(76)$, the male DNA is also more methylated(77). HR6A, is a maternal protein which is involved in the repair and modification of histones; oocytes of mice that are deficient in this protein, can be fertilized but the resulting embryos are arrested in 2-cell embryos(78). NPM2, is a maternal nuclear protein identified in Xenopus frog, which is related to the process of sperm DNA decondensation(79). Embryos of mice npm2-/- presented an arrest at the zygote stage showing severe damage in heterochromatin at the level of the deacetylation of histones(80).

Within the first hours post-fertilization, the male genome suffers a very active demethylation that involves the action of the protein Cytidine deaminase AID(81), that causes an abrupt loss of methyl present in the DNA, during the first cycle of cell division(82). This process has been confirmed in mammals such as cattle(85-87) and mouse $(83,84)$. The demethylation of the paternal genome is mediated by oxidation of 5 
día embrionario 9.5 a 10.5 con malformaciones relacionadas con defectos en el cierre del tubo neural $(72,73)$. Antes del proceso de fertilización, el DNA de ambos gametos está muy compactado e hipermetilado, el DNA masculino está empaquetado en protaminas, mientras que el DNA del ovocito lo está en histonas(74). Una vez que se lleva a cabo la fecundación, la membrana del espermatozoide se fusiona con la membrana plasmática del ovocito y el núcleo espermático es depositado en el citoplasma del ovocito(11). En este punto se generan dos pronúcleos, uno femenino y otro masculino, donde ambos genomas altamente especializados deben combinarse, integrarse y reprogramarse, para permitir la pluripotencia y el desarrollo embrionario.

Después de la fertilización, el genoma masculino se somete a una descondensación y es reempaquetado con histonas presentes en el citoplasma del ovocito(75). Una vez que ambos genomas haploides se encuentran empaquetados con histonas, comienza la replicación del DNA de forma independiente en cada pronúcleo. En este punto del desarrollo embrionario, los niveles de transcripción son bajos, siendo más altos en el pronúcleo masculino que en el femenino. Las histonas que empaquetan el genoma masculino están más acetiladas que las encontradas en el pronúcleo femenino(76), además el DNA masculino está más metilado(77). HR6A, es una proteína materna que está implicada en la reparación y la modificación de histonas; ovocitos provenientes de ratones que son deficientes de esta proteína, pueden ser fertilizados, pero los embriones resultantes son arrestados en embriones de 2 células(78). NPM2, es una proteína materna nuclear identificada en la rana Xenopus, la cual está relacionada con el proceso de descondensación del DNA espermático(79). Embriones de ratones npm2\%presentan un arresto en la etapa de cigoto mostrando severos daños en la heterocromatina a nivel de la desacetilación de histonas(80).

Dentro de las primeras horas post-fertilización, el genoma masculino sufre una desmetilación methycitosyne $(5 \mathrm{mC})$ to 5 -hidromethylcytosine $(5 \mathrm{hmC})(88)$, whose reaction is catalyzed by a protein enzyme of maternal origin called Tet methylcytosine dioxygenase 3 (TET3)(89). tet3 is a gene which is predominantly expressed in oocytes, this expression persists after fertilization in the zygote and it is shot down during the stage of two cells(88). Embryos of mouse tet3-/show that there is loss of demethylation in male pronucleus in the zygote stage $(89)$; this coincides with the results obtained by immunofluorescence, showing that this protein is enriched into the male pronucleus of normal mouse embryos(89).

GSE is a maternal protein which is expressed up from the blastocyst stage to the immature oocyte, although the abundance of this protein decreases from the blastocyst stage $(90,91)$. In the zygote GSE protein is found preferentially in the male pronucleus attached to chromatin(91). Embryos of mice deficient of GSE showed a significant decrease in the amount of $5 \mathrm{hmC}$ and an increase in $5 \mathrm{mC}$ into the male pronucleus; where the female pronucleus showed no difference with the normal zygote(91). This results open the possibility that the process of demethylation in the male genome is since GSE joins chromatin, and acting in synchrony with the enzyme TET3 to oxidize $5 \mathrm{cM}$ to $5 \mathrm{hmC}$. At the same time, unlike the parental genome, in the maternal genome demethylation occurs gradually through several cycles of cell division(92). This is due to the fact that the maternal protein STELLA, also known as PGC7, protects the DNA demethylation, preventing the oxidation of $5 \mathrm{cM}$ to $5 \mathrm{hmC}(93)$. STELLA is present in the primordial germ cells and their function is required for embryonic development $(94,95)$, binds to the protein 5 union Ran and is transported to the nucleus, where it joined the lysine 9 of histone 3 in maternal chromatin, which reduces the union of the enzyme TET3, implying $5 \mathrm{mC}$ sites without oxidation $(92,96)$. Oocytes stella-/- have a normal methylation in the ICRs, but embryos derived from them are hypomethylated in these regions, both in maternal as paternal genome(92), and 
muy activa que involucra la acción de la proteína citidina deaminasa $\operatorname{AID}(81)$, que provoca una pérdida abrupta de los metilos presentes en el DNA, esto sucede durante el primer ciclo de división celular(82); este proceso ha sido confirmado en mamíferos como ratón $(83,84)$ y bovinos(85-87). La desmetilación del genoma paterno está mediada por la oxidación de 5 metilcisoticina $(5 \mathrm{mC})$ a 5 -hidromethilcitosina (5 $\mathrm{hmC})(88)$, cuya reacción esta catalizada por una enzima proteica de origen materno denominada Tet metilcytocina dioxygenasa 3 (TET3)(89). tet3 es un gen que se expresa predominantemente en ovocitos; dicha expresión persiste después de la fertilización en el cigoto y es abatida durante el estadio de dos células(88). Embriones de ratón tet3-/- muestran que hay pérdida de desmetilación en el pronúcleo masculino en la etapa de cigoto(89); esto coincide con los resultados obtenidos por inmunofluorescencia, donde se observa que esta proteína está enriquecida en el pronúcleo masculino de embriones de ratón normales(89).

GSE es una proteína materna que se expresa desde el ovocito inmaduro hasta la etapa de blastocisto, aunque la abundancia de esta proteína disminuye a partir de este estadio $(90,91)$. En el cigoto la proteina GSE se encuentra de forma preferencial en el pronúcleo masculino unida a la cromatina(91). Embriones de ratones deficientes de GSE mostraron una significante disminución de la cantidad de $5 \mathrm{hmC}$ y un aumento en $5 \mathrm{mC}$ en el pronúcleo masculino; donde el pronúcleo femenino no mostró ninguna diferencia con el cigoto normal(91). Estos resultados abren la posibilidad de que el proceso de desmetilación en el genoma masculino es debido a que GSE se une a la cromatina, y actúa en sincronía con la enzima TET3 para oxidar $5 \mathrm{mC}$ a $5 \mathrm{hmC}$. Al mismo tiempo, a diferencia del genoma paterno, en el genoma materno la desmetilación sucede de forma paulatina a través de varios ciclos de división celular(92). Esto es debido a que la proteína materna STELLA, también conocida como PGC7, protege al DNA de la desmetilación, impidiendo la oxidación de $5 \mathrm{mC}$ a $5 \mathrm{hmC}(93)$. specifically the female pronucleus presents a global loss of methylation, which by immunofluorescence assay has been associated with the enzyme TET3 present in this pronucleus, what is not seen in normal embryos $(69,93)$. Going from zygote to 2-cells embryo, most of the male genome is demethylated and only persist the ICRs methylated of mono-allelic expression, in the case of the maternal genome ICRs regions are methylated due to the protection provided by STELLA; however in the paternal genome given the speed that occurs in the process of demethylation, keeping the ICRs regions methylated is a problem, which is solved thanks to the action of the maternal protein TRIM28(97). Already for the stage of morula, the greater part of genome, regardless of their origin, must be demethylated and the unique methylation signals that should be present are those corresponding to the ICRs of mono-allelic expression for each specific haploid genome $(77,98)$.

After that, already at the stage of blastocyst, methylation begins to become active, so that there is more methylation in the cells of the inner cell mass that give rise to the embryo, than in the cells of the trophectoderm that give rise to the placenta(68). Maintenance of the methylation of the ICRs, is key point for proper embryonic development; this process involves various proteins, most of them with activity of methyltransferases and a maternal origin of expression. DNMT10 comes from the expression of a maternal mRNA specific form the oocyte(99), is a DNA methyltransferase responsible for the maintenance of methylation in the ICR during early embryogenesis, prior to the implantation of the blastocyst. In mouse embryos, derived from oocytes dnmt10-/-, have half of the ICRs regions methylated in embryos of $9.5 \mathrm{~d}$ as opposed to the normal embryos, who have completed this process(100). Another mRNA with maternal effect is zfp57, which encodes a transcription factor required for the establishment of methylation level of germ line and also participates in the maintenance of 
STELLA está presente en las células primordiales germinales y su función es requerida para el desarrollo embrionario(94,95), se une a la proteína Ran de unión 5 y es transportada hacia el núcleo, donde se une a la lisina 9 de la histona 3 en la cromatina materna, lo que reduce la unión de la enzima TET3, lo que implica los sitios de $5 \mathrm{mC}$ sin oxidarse $(92,96)$. Ovocitos stella-/- tienen una metilación normal en los ICRs, pero los embriones derivados de ellos están hipometilados en dichas regiones, tanto en el genoma materno como paterno(92), y específicamente el pronúcleo femenino presenta una pérdida global de la metilación, que por ensayos de inmunofluorescencia se ha relacionado con la de la enzima TET3 presente en este pronúcleo, lo que no se observa en los embriones normales $(69,93)$. Al pasar de cigoto a embrión de 2 células, la mayor parte del genoma masculino está desmetilado y sólo persisten metilados los ICRs de expresión monoalélica, en el caso del genoma materno las regiones ICRs permanecen metiladas debido a la protección brindada por STELLA; sin embargo en el genoma paterno dada la velocidad que se da en el proceso de desmetilación, el mantener las regiones ICRs metiladas es un problema, el cual es resuelto gracias a la acción de la proteína materna TRIM28(97). Ya para el estadio de mórula, la mayor parte de todo el genoma, independientemente de su origen, debe de estar desmetilado y las únicas señales de metilación que deben estar presentes son las correspondientes a los ICRs de expresión monoalélica específicos de cada genoma haploide(77,98).

Después de esto, ya en el estadio de blastocisto, la metilación comienza a volverse activa, de forma tal que se observa más metilación en las células de la masa celular interna que dan origen al embrión, que en las células del trofoectodermo que da origen a la placenta(68). El mantenimiento de la metilación de los ICRs, es punto clave para que el desarrollo embrionario ocurra de manera adecuada; en este proceso intervienen diversas proteínas, la mayoría de ellas con actividad de metiltransferasas y con un origen patterns of methylation in the early embryogenesis. Embryos whose gen was removed, have a total loss of methylation patterns and die on the zygote stage(10).

Maternal effect on the activation of the embryonic genome

Once fertilization occurs during the oocyte embryo transition, it begins a massive degradation of the maternal mRNA, which is key for proper activation of the embryonic genome $(25,101)$. In Xenopus, Zebrafish and mouse this mechanism occurs because happens a deadenylation of the extreme 3'UTR of the RNAm promoted by the CCR4/NOT complex, which in turn was activated by its bond with the protein GW182, which in turn interacts with the RISCs via miRNA or endo-siRNA $(102,103)$. The action of miRNAs on maternal mRNA degradation has been clear in Zebrafish embryos, which shows that the miR430 is abundant in the embryonic activation point, just at the moment the degradation of the maternal transcripts takes place(44). Recent studies have shown that in the bovine, maternal mRNA as NOBOX and NPM2 are regulated under the action of the miR-181st and miR196a, respectively $(104,105)$. It is important to point out that the route of the degradation mediated by miRNAs is present only during the activation of the embryonic genome, and is absent during the oogenesis and in the initial stages of the embryo $(47,52,54,106)$.

The activation of the embryonic genome requires the remodeling of chromatin, where nucleosomes are restructured or moved with regions to be transcribed. The best characterized proteins responsible for this process include the SWI/SNF (first described in yeast), ISWI (described in Drosophila), CHD (described in Xenopus) and the INO88 (described in yeast)(107). brg1 is a mouse maternal transcript that encodes a component of the family of SWI/SNF proteins, responsible for the remodeling of chromatin process during the activation of the embryonic genome. Embryos 
de expresión materno. DNMT1o proviene de la expresión de un RNAm materno de forma específica en el ovocito(99), es una DNA metiltransferasa responsable del mantenimiento de la metilación en los ICR a lo largo de la embriogénesis temprana, previo a la implantación del blastocisto. En embriones de ratón, derivados de ovocitos dnmt10\%-, presentan la mitad de la regiones ICRs metiladas en embriones de 9.5 días a diferencia de los embriones normales, los que tienen completado este proceso(100). Otro RNAm con efecto materno es $z f p 57$, el cual codifica para un factor de transcripción requerido para el establecimiento de la metilación a nivel de la línea germinal y además participa en el mantenimiento de los patrones de metilación en la embriogénesis temprana. Embriones a los que se les eliminó este gen presentan una pérdida total de los patrones de metilación y mueren en la etapa de cigoto(10).

Efecto materno sobre la activación del genoma embrionario

Una vez que sucede la fertilización, durante la transición ovocito a embrión, comienza una degradación masiva de los RNAm maternos, lo que es clave para que se dé una adecuada activación del genoma embrionario $(25,101)$. En Zebrafish, Xenopus y ratón este mecanismo se da debido a que sucede una desadenilación del extremo 3'UTR del RNAm promovida por el complejo CCR4/NOT, que a su vez fue activado por su unión con la proteína GW182, que a su vez interacciona con el RISCs vía miRNA o endosiRNA $(102,103)$. La acción de miRNAs sobre la degradación de RNAm maternos ha quedado clara en embriones del Zebrafish, donde se observa que el miR430 es abundante en el punto de la activación embrionaria, justo en el momento en que sucede la degradación de los transcritos maternos(44). Estudios recientes han demostrado que en el bovino, RNAm maternos como NOBOX y NPM2 son regulados bajo la acción de los miR-181a y miR196a, respectivamente $(104,105)$. Es importante señalar que la vía de degradación mediada por los of mice brg1-/- are arrested at the 2-4 cells stage(108).

After the remodeling of chromatin, the embryonic genome begins to be accessible to the action of the transcription factors, which are of maternal origin. HSF1, is a transcription factor that acts as a master gene, regulating the expression of stress-inducible genes, and is highly expressed in mouse oocytes. Although its expression is not restricted to oocytes, deficient females of this gene have defects at the level of the meiosis(109) and embryos derived from oocytes of these females are arrested in zygotes(110). Basonuclina1, encoded by the mRNA maternal bnc1, is a transcription factor with domains of zinc fingers, abundant in germinal cells; acts on transcription mediated by RNA polymerases enzymes I and II. Oocytes of mouse with this deleted gene show defects in oogenesis, fertilization and the transition oocyte-embryo(111). Another transcription of maternal origin, is the protein CTCF, which is involved with the regulation of the genome at the epigenetic level, including the inactivation of the $\mathrm{X}$ chromosome in embryonic stem cells; his absence is related to defects at the level of the meiosis and during the preimplantation of the embryo(112).

After fertilization, the zygote, generated from the combination of the two haploid pronuclei, now with the genome reprogrammed, acquires totipotency that is the ability of these cells to form a complete organism from the three embryonic lineages: endoderm, ectoderm and mesoderm(11). OCT-4, is a maternal protein whose action is related to the process of transition of the oocyte to the embryo, the oct-4 gene is expressed during the oogenesis, its expression persists until 2-cell embryos and its removal causes an arrest during the formation of the zygote(113). It is important to clarify that the maternal form of the oct-4 gene is different from the way this gene is expressed at the ICM in the blastocyst embryo; this form of expression leads to the phenotype of pluripotency in the embryonic stem cells 
miRNAs está presente sólo durante la activación del genoma embrionario, y se encuentra ausente durante la ovogénesis y en las etapas iniciales del embrión(47,52,54,106).

La activación del genoma embrionario requiere la remodelación de la cromatina, donde se reestructuran o mueven los nucleosomas con regiones a ser transcritas. De las proteínas mejor caracterizadas encargadas de este proceso destacan la SWI/SNF (descrita primeramente en levaduras), ISWI (descrita en Drosophila), CHD (Descrita en Xenopus) y la INO88 (descrita en levaduras)(107). brg1 es un transcrito materno de ratón que codifica para un componente de la familia de proteínas SWI/ SNF, encargadas de los procesos de remodelación de la cromatina durante la activación del genoma embrionario. Embriones de ratones brg 1 -/- se arrestan en el estadio de 2 a 4 células(108).

Después de la remodelación de la cromatina, el genoma embrionario comienza a ser accesible a la acción de factores de transcripción, que son de origen materno. HSF1, es un factor de transcripción que actúa como un gen maestro regulando la expresión de genes inducibles al estrés, y es altamente expresado en ovocitos de ratón. Aunque su expresión no está limitada a los ovocitos, hembras deficientes de este gen tienen defectos a nivel de la meiosis(109) y los embriones derivados de los ovocitos de estas hembras son arrestados en cigotos(110). Basonuclina1, codificada por el RNAm materno bnc1, es un factor de transcripción con dominios de dedos de zinc, abundante en células germinales; actúa sobre la transcripción mediada por las enzimas RNA polimerasas I y II. Ovocitos de ratón con este gen eliminado, presentan defectos en la ovogénesis, fertilización y en la transición ovocito-embrión(111). Otro factor de transcripción de origen materno, es la proteína CTCF, que está implicada con la regulación del genoma a nivel epigenético, incluyendo la inactivación del cromosoma $X$ en células madre embrionarias; su ausencia está relacionada con defectos a nivel de la meiosis y durante la preimplantanciación del embrión(112).
$(114,115)$, in other words the RNAm of oct- 4 expressed during the oogenesis disappears before the activation of the embryonic genome, after this, the embryo activates its own transcription process and it is when express its own mRNA of oct-4 which is specific to the ICM. More related to pluripotency maternal transcription factor, is SOX2, which like OCT-4, is highly expressed in oocytes and crosses the nucleus of 2-cells embryos, where it is kept until the blastocyst stage, found in the nucleus of the cells of the ICM, whereas it is redistributed in the cytoplasm of trophectoderm cells. Its embryonic expression is not detected until the stage of morula, and sox2 gene deficient embryos do not survive past the early implantation(116).

\section{Maternal effect on maternal mRNA degradation}

As already mentioned, after the activation of the embryonic genome most of the maternal mRNA is degraded. This mechanism is carried out ironically by proteins of maternal origin. AGO2 and DICER proteins are of maternal origin and act on the processing of the microRNAs(51). Dicer-/- murine oocytes are unable to complete meiosis due to a defect in the organization of the mitotic spindle, which leads to a bad migration of chromosomes at the equator of the cell $(11,60)$. For its part the ago 2 gene loss, causes an arrest in 2-cells embryos(117). Another gene involved in degradation of maternal detritus is zfp3612 who encodes a protein with zinc finger domains, which is involved in the promotion of mRNA degradation at joining elements $A U$ in the UTR' 3 of mRNA targets; embryos of mice deficient of this gene, are unable to pass beyond the 2-cell stage(118). ATG5, is a maternal protein, related to degradation processes for autophagy in lysosomes; embryos derived from oocytes of mice atg5-/- do not pass beyond the 4 to 8 cells stage(119). This is consistent with that found in the pig model, which showed that the maternal mRNA degradation process is related to the process of autophagy in early embryos 
Posterior a la fertilización, el cigoto generado a partir de la conjugación de los dos pronúcleos haploides, ya con el genoma reprogramado, adquiere totipotencia, que es la capacidad de estas células de formar un organismo completo a partir de los tres linajes embrionarios: endodermo, ectodermo y mesodermo(11). OCT-4, es una proteína materna cuya acción se relaciona con el proceso de transición del ovocito al embrión, el gen oct-4 es expresado durante la ovogénesis, su expresión persiste hasta embriones de dos células y su eliminación provoca un arresto durante la formación del cigoto(113). Es importante aclarar que la forma materna del gen oct-4, es diferente a la forma expresada de este gen en la ICM en el blastocisto del embrión; esta forma de expresión conduce al fenotipo de pluripotencia en las células madre embrionarias(114,115), en otras palabras el RNAm de oct-4 expresado durante la ovogénesis desaparece antes de la activación del genoma embrionario; después de esto, el embrión activa su propia maquinaria de trascripción y es cuando expresa su propio RNAm de oct-4 que es específico de la ICM. Un factor de transcripción materno más relacionado con pluripotencia, es SOX2, el cual al igual que OCT-4, es altamente expresado en ovocitos y atraviesa el núcleo de los embriones de dos células, donde se mantiene hasta la etapa de blastocisto, encontrándose en el núcleo de las células de la ICM, mientras que se redistribuye en el citoplasma de células del trofoectodemo. Su expresión embrionaria no es detectada hasta el estadio de mórula, y embriones deficientes del gen sox2 no sobreviven pasada la implantación temprana(116).

Efecto materno sobre la degradación de RNAm maternos

Como ya se mencionó, después de la activación del genoma embrionario la mayoría de los RNAm maternos son degradados. Este mecanismo es llevado a cabo irónicamente por proteínas de origen materno. Las proteínas DICER y AGO2 son de origen materno y actúan en el procesamiento de los microRNAs(51). Ovocitos prior to the activation of the embryonic genome(120). The work of Xu et al(120) does not indicate whether this process of autophagy acts after the action of the miRNAs, only shows that by adding autophagy inhibitor 3-metiladedina to early embryonic cultures, the expression of maternal mRNA as c-mos, gdf9 and bmp15 remains still in embryonic stages of 4 cells. It would be interesting to find out whether autophagocityc vacuoles are comprised with the maternal mRNA debris.

\section{Maternal effect during the preimplantation}

After fertilization, once the chromosomes are packaged in histones and the genome has been replicated, the syngamy occurs. At this point, both the male and the female pronucleus are very near each other, so that both nuclear membranes begin to intermix. After this, the nuclear membrane breaks down giving opportunity to the microtubules of the mitotic spindle to join the centromeres of the chromosomes and the first mitotic division is carried out(11). In mouse, already as a zygote or 1-cell embryo, transcription begins to be activated and the synthesis of new proteins is observed before the 2-cell stadium, resulting in the activation of the embryonic genome $(121,122)$. This process depending on the species, occurs at different stages of embryonic development; for bovines activation occur in the embryo of 8 to 16 cells(123), as opposed to the mouse that takes place at the 2-cells stage(124), while in Xenopus happens in half gastrula stage(125); in the case of the human, activation of the embryonic genome occurs during the 8-cells embryo(123). During this mechanism has been observed that the action of the Tsar-1 maternal protein is important for the adequate syngamy. Tsar-1 is a cytoplasmic protein of maternal origin highly conserved in different species such as the Zebrafish, human, pig, and bovine(126-129). His absence is related to defects in the process of syngamy, taking place an embryonic arrest at the 1-cell stage(130).

There is a group of native proteins that are grouped in the subcortical part of the embryo, 
murinos Dicer/- son incapaces de completar la meiosis debido a un defecto en la organización del huso mitótico que conlleva a una mala migración de los cromosomas en el ecuador de la célula(11,60). Por su parte la pérdida del gen ago2, ocasiona un arresto en embriones de dos células(117). Otro gen implicado en la degradación de detritos maternales es zfp3612 quien codifica para una proteína con dominios de dedos de zinc, la cual está involucrada en la promoción de la degradación de RNAm al unirse a los elementos $A U$ en el UTR'3 de RNAm blancos; embriones de ratones deficientes de este gen, son incapaces de pasar más allá del estadio de dos células(118). ATG5, es una proteína materna, relacionada con los procesos de degradación por autofagia en los lisosomas; embriones derivados de ovocitos de ratones atg5-/- no pasan más allá del estadio de 4 a 8 células(119). Esto coincide con lo encontrado en el modelo porcino, donde se demostró que el proceso de degradación de RNAm maternos está relacionado con el proceso de autofagia en embriones tempranos previo a la activación del genoma embrionario(120). El trabajo de Xu et al(120) no indica si este proceso de autofagia actúa después de la acción de los miRNAs, sólo muestra que al adicionar el inhibidor de autophagia 3-metiladedina a cultivos embrionarios tempranos, la expresión de RNAm maternos como c-mos, gdf9 y bmp 15 permanece aún en estadios embrionarios de 4 células. Sería interesante dilucidar si las vacuolas autofagocíticas se conforman con los detritos de RNAm maternos.

\section{Efecto materno durante la preimplantación}

Después de la fertilización, una vez que los cromosomas están empaquetados en histonas y que el genoma ha sido replicado, ocurre la singamia. En este momento, tanto el pronúcleo femenino como el masculino se encuentran muy próximos el uno del otro, de forma tal que ambas membranas nucleares comienzan a interdigitarse. Posterior a esto, la membrana nuclear se rompe dando oportunidad para que los microtúbulos del huso mitótico se unan al and, at least in mice, are related to the progression of the zygote to 2-cell embryos. The proteins that make up this group are MATER(131), FLOPED(10), TLE6(10), FILIA(132) and PADI6(133). The absence of any of these proteins does not affect the ovarian follicle development or the development of germ cells; however, the absence of any of them, produces seemingly normal but infertile individuals, females produce eggs capable of being fertilized, but during embryonic development does not occur the maternal subcortical complex formation, and the phenotypes observed in embryos deficient of the genes that encode for some of these proteins, present arrests in 2-cell embryos $(10,131,134,135)$.

\section{MATERNAL MRNA IN THE BOVINE}

During the growth phase cattle oocytes synthesize a large amount of mRNA, this can be seen from the secondary follicle and is maintained up to the tertiary follicle $(136,137)$. In other words, in the bovine system transcription of mRNA begins to decline when the oocyte completes its growth and reactive meiosis II towards metaphase II(138). Likewise, this process is mediated by the deadenylation of the extreme 3 'UTR of the mRNA, through the action of proteins such as CPEB and eIF4G(139). It has been shown that mature oocytes present mRNA with tails of polyadenin shorter than in those immature oocytes; however these mRNA with long tails of adenines, after fertilization in the stadium of 2 cells are deleted(137). In cattle maternal mRNA storage during oogenesis is necessary to carry out a proper embryonic development(137). To date, few maternal factors have been described in cattle (Table 2), which include DICER, DROSHA, NMP2, MATER, ZAR1, NOBOX, ALPHA8, JY1 and DMT1.

Burrola-Barraza et a $(60,140)$ and Mondou et a(141) analyzing the expression pattern of the gene DICER and DROSHA, respectively, in immature and mature oocytes as well as in the various early embryonic stages, found an 
centrómero de los cromosomas y se lleve a cabo la primera división mitótica(11). En ratón, ya como cigoto o embrión de 1 célula, la transcripción empieza a activarse y la síntesis de nuevas proteínas se observa antes del estadio de dos células, dando lugar a la activación del genoma embrionario(121,122). Este proceso dependiendo de la especie, ocurre en diferentes etapas del desarrollo embrionario, para los bovinos la activación ocurren en el embrión de 8 a 16 células(123), a diferencia del ratón que ocurre en la etapa de 2 células(124), mientras que en Xenopus sucede en la etapa de gástrula media(125); en el caso del humano la activación del genoma embrionario ocurre durante la etapa del embrión en 8 células(123). Durante este mecanismo se ha observado que la acción de la proteína materna ZAR-1 es importante para que la singamia se dé en forma adecuada. ZAR-1, es una proteína citoplasmática de origen materno altamente conservada en diversas especies como el zebrafish, humano, cerdo y bovino(126-129). Su ausencia está relacionada con defectos en el proceso de singamia observándose un arresto embrionario en el estadio de 1 célula(130).

Existe un grupo de proteínas maternas que son agrupadas en la parte subcortical del embrión y, al menos en el ratón, están relacionadas con la progresión del cigoto a embriones de dos células. Las proteínas que componen este grupo son MATER(131), FLOPED(10), TLE6(10), FILIA (132) y PADI6(133). La ausencia de cualquiera de estas proteínas no afecta el desarrollo del folículo ovárico ni el desarrollo de células germinales; sin embargo, la ausencia de cualquiera de ellas, produce individuos aparentemente normales pero estériles, las hembras producen ovocitos capaces de ser fertilizados, pero durante el desarrollo embrionario no sucede la formación del complejo subcortical materno, y los fenotipos observados en embriones deficientes de los genes que codifican para algunas de estas proteínas, presentan arrestos en embriones de dos células $(10,131,134,135)$. expression very similar to the already reported in mice, which consisted in an increase of expression in mature oocytes that remained unchanged up to 2 to 8 -cell embryos, then significantly lower at 16 -cell embryos and reactivated at the blastocyst stage. This could mean that DICER and DROSHA are involved during the oocyte maturation in gene repression by miRNAs, and it is required in the stages prior to the activation of the embryonic genome, where is repressed(60). Likewise, the expression of the gene MATER has been detected in the oocytes of primary follicles, decreasing strongly during maturation, as well as during the embryo division, finding minimum in morula and blastocyst(142). ZAR1, unlike the mouse where it is only seen in the ovary, zygote and 2-cell embryos, in the adult bovine is located in ovary, testes, muscle, skeleton, and myocardium; expressed also in the oocyte, zygote and all the embryonic stages until the formation of the blastocyst(129). Their level of expression is constant in embryos developed in vitro, with the exception of the 4-cell stage where there is a significant increase, therefore the translation of this gene happens during this stage of development of the embryo, which indicates that it is present in cattle, but their pattern of expression is different from the mouse(126).

Another maternal factor involved in the embryonic development of cattle, is the importin Alpha 8 (KPNA7), which belongs to the family of Alpha, which are protein transporters responsible for transporting nuclear proteins as protein DNMT1(143) and transcription factors as Stat3(144). The expression of the messenger that encodes for KPNA7, is abundant in immature oocytes and oocytes in metaphase II, as well as in embryos in the early stages before the embryonic genome activation, but is barely detectable in morula and blastocyst; in addition, embryos with the inactive gene KPNA7 result in a decrease in the proportion of embryos developed to the stage of blastocyst(145). Bettegowda et al(146) discovered and characterized the JY-1 gene, whose protein is specific to the oocyte, is responsible for the 


\section{RNAT MATERNOS EN EL BOVINO}

Durante la fase de crecimiento los ovocitos bovinos sintetizan una gran cantidad de RNAm, esto se observa a partir del folículo secundario y es mantenida hasta el folículo terciario $(136,137)$. En otras palabras, en el sistema bovino la transcripción de RNAm empieza a decaer cuando el ovocito termina su crecimiento y reactiva la meiosis II rumbo a metafase II(138). Así mismo este proceso es mediado por la desadenilación del extremo 3'UTR del RNAm, a través de la acción de proteínas como CPEB y eIF4G(139). Se ha demostrado que los ovocitos maduros presentan RNAm con colas de poliadeninas más cortas que en aquellos ovocitos que son inmaduros; sin embargo estos RNAm con colas largas de adeninas, después de la fertilización en el estadio de 2 células son eliminados(137). En el bovino el almacenaje de RNAm maternos durante la ovogénesis es necesario para que se lleve a cabo un correcto desarrollo embrionario(137). A la fecha, en el bovino se han descrito pocos factores maternos (Cuadro 2), dentro de los que destacan DICER, DROSHA, NMP2, MATER, ZAR1, NOBOX, ALPHA8, JY1 y DMT1.

Burrola-Barraza et a $(60,140)$ y Mondou et al(141) al analizar el patrón de expresión del gen DICER y DROSHA, respectivamente, en ovocitos inmaduros y maduros, así como en los diferentes estadios embrionarios tempranos, encontraron una expresión muy similar a la ya reportada en el ratón, la cual consistió en un incremento de la expresión en ovocitos maduros que se mantuvo sin cambios hasta embriones de 2 a 8 células, para luego disminuir significativamente en embriones de 16 células y reactivarse en la etapa de blastocisto. Esto pudiera implicar que DICER y DROSHA participan durante la maduración del ovocito en la represión genética vía miRNAs, y es necesaria en los estadios previos a la activación del genoma embrionario, donde es reprimida(60). Así mismo, la expresión del gen MATER ha sido detectado en los ovocitos de folículos primarios, disminuyendo fuertemente durante la maduración, así como durante la división embrionaria, encontrándose mínima en regulation of granulosa cells and plays a key role in the regulation of fertility in mammals, which is related to the presence of single nucleotide polymorphisms simple (SNPs) within exon 3 of the gene(147). The JY-1 mRNA is detectable throughout the folliculogenesis from immature oocytes to the oocyte at metaphase II; after fertilization it is present in early bovine embryos up to the stage of 8 cells(146). NOBOX is a protein that acts as a transcription factor(148), whose messenger is preferentially expressed in the bovine ovary. This protein is present during all the folliculogenesis in oocytes and acts in the early developing of embryos, since this inactive gene is unable to reach the blastocyst stage(149). Recently it was found that the messenger of the maternal gene NOBOX has binding sites for the miR-196a in his extreme UTR 3', demonstrating that this miRNA is a negative regulator during early embryogenesis in cattle. The miR-196a is present in the oocyte and embryo, its expression is increased in the embryonic stage of 4 to 8 cells(105). The nucleoplasmin 2 (NPM2) is a specific protein from the egg that acts on the nuclear organization in early embryonic development(80). Both the expression profile and the level of NMP2 protein in bovines show that is more abundant in mature and immature oocytes in early embryos stage. The abundance of the mRNA of NMP2 decreases starting from zygotes, increasing slightly in 2-cell embryos, it decreases again in 4-cell embryos and decreases drastically from 16-cell embryos; from morula NPM2 expression is minimal. This indicates that NMP2 may be required for the nuclear organization during the activation of the embryonic genome. The transcript NMP2 has a binding site on its UTR' 3 end for the miR-181st and experiments in cattle showed that the translation of NPM2 is suppressed by this miRNA(104).

Another maternal mRNA identified in cattle by Golding et $a(150)$ is DMT1, that generates the methyltransferase 1; analysis of the expression of this gene in early embryos revealed that it is expressed in 2-cell embryos and begins to slow down at the 8-cell stage, to suppress 
mórula y blastocisto(142). ZAR1, a diferencia del ratón donde sólo se ve en ovario, cigoto y embrión de 2 células, en el bovino adulto se encuentra en ovario, testículos, músculo, esqueleto y miocardio. También se expresa en el ovocito, cigoto y en todos los estadios embrionarios hasta la formación del blastocisto(129). Su nivel de expresión es constante en embriones desarrollados in vitro, a excepción del estadio de 4 células donde hay un aumento significativo, por lo tanto la traducción de este gen sucede durante esta etapa de desarrollo del embrión, lo cual indica que se encuentra presente en el bovino, pero su patrón de expresión es diferente a la del ratón(126).

Otro factor materno involucrado en el desarrollo embrionario de bovinos, es la importina alfa 8 (KPNA7), la cual pertenece a la familia de importinas alfa, que son transportadores proteicos encargados de transportar proteínas nucleares como la proteína DNMT1(143) y factores de transcripción como Stat3(144). La expresión del mensajero que codifica para KPNA7, es abundante en ovocitos inmaduros y en ovocitos en metafase II, así como en embriones en estadios tempranos antes de la activación del genoma embrionario, pero es apenas detectable en mórula y blastocisto; además embriones con el gen KPNA7 inactivo resultan en un decremento en la proporción de embriones desarrollados hasta el estadio de blastocisto(145). Bettegowda et al(146) descubrieron y caracterizaron el gen $J Y$-1, cuya proteína es específica del ovocito, se encarga de la regulación de las células de la granulosa y tiene una función clave en la regulación de la fertilidad en mamíferos, que se relaciona con la presencia de polimorfismos de nucleótidos simples (SNPs) dentro del exón 3 del gen(147). El RNAm de JY-1 es detectable a lo largo de la folículogénesis desde ovocitos inmaduros hasta el ovocito en metafase II; después de la fertilización está presente en embriones tempranos de bovino hasta la etapa de 8 células(146). NOBOX es una proteína que actúa como factor de transcripción(148), cuyo significantly at the blastocyst stage. This same group conducted in zygotes microinjection with an artificial siRNA that blocked the expression of this gene and observed that embryos had a normal development until the 8-cell stage, here after the growth was arrested(150).

In regard to the action of the small RNAs, like Tang et al(46) in 2007, Tesfaye et a(151) both found a differential profile of miRNAs in mature and immature oocytes; miRNAs like miR-145, miR-292-3p and miR-496, show a significant expression increase in mature oocytes which implies that these miRNAs may be involved in the process of competence of bovine oocytes. Inside the miRNAs that Tesfaye et al(151) found, are those who being already present from the mature oocyte after fertilization, remain present until stages prior to the activation of the embryonic genome; these include the miR-145, miR-208, miR-207 and miR-125a. Coupled with the above, Abd El Naby et a(152) identified that the miR-205, miR-150, miR-96, miR-122, miR-146a and miR-146b-5p are expressed consistently in the bovine oocyte and its expression begins to fall after $8 \mathrm{~h}$ of in vitro maturation of oocytes, but remain after fertilization until the 4-cells stage, where they begin to decline abruptly in the 8-cell stage. Consistent with this, Miles et a/(153) showed that the miR-let7b, miR-let7i and miR-106a are expressed specifically during the process of maturation of bovine oocytes. The pattern of these miRNAs expression involves its maternal origin as Tang et al(46) described it for the mouse. Interestingly Mondou et al(141), found that miR-21 and miR-130 have a little expression in immature and mature oocytes that changes significantly after fertilization, where it is observed that increases their expression from the 2-cell stage, staying high until the 8-cell stage, to become depressed at the blastocyst stage.

Considering the precedent that the miRNAs are not active during oocyte maturation, nor are essential to embryo development, miR-21 and miR-130 who take an essential role in the 
mensajero es preferentemente expresado en ovario del bovino. Esta proteína está presente durante toda la foliculogénesis en los ovocitos y actúa en el desarrollo temprano de embriones dado que embriones con este gen inactivo son incapaces de llegar a la etapa de blastocisto(149). Recientemente se encontró que el mensajero del gen materno NOBOX tiene sitios de unión para el miR-196a en su extremo UTR 3', demostrando que este miRNA es un regulador negativo durante la embriogénesis temprana en el bovino. El miR-196a está presente en el ovocito y en el embrión, su expresión se incrementa en el estadio embrionario de 4 y 8 células(105). La Nucleoplasmina 2 (NPM2) es una proteína específica del ovocito que actúa en la organización nuclear en el desarrollo embrionario temprano(80). Tanto el perfil de expresión como el nivel de proteína de NMP2 en bovinos, muestran que es más abundante en ovocitos inmaduros y maduros, que en embriones de estadios tempranos. La abundancia del RNAm de NMP2 decrece a partir de cigotos, aumentando un poco en embriones de 2 células, disminuye de nuevo en embriones de 4 células y decrece drásticamente a partir de embriones de 16 células; a partir de mórula la expresión de NPM2 es mínima. Esto indica que NMP2 podría ser requerida para la organización nuclear durante la activación del genoma embrionario. El transcrito de NMP2 tiene un sitio de unión en su extremo UTR ' 3 para el miR-181a y en experimentos en bovino se demostró que la traducción de NPM2 es reprimida por este miRNA(104).

Otro RNAm materno identificado en el bovino por el grupo de Golding et al(150) es DMT1, que genera la metiltransferasa 1 ; análisis de la expresión de este gen en embriones tempranos reveló que está expresada en embriones en estadios de 2 células y empieza a decaer en el estadio de 8 células, para suprimirse significativamente en la etapa de blastocistos. Este mismo grupo realizó en cigotos microinyecion con un siRNA artificial que bloqueaba la expresión de este gen y observó que los embriones tenían un desarrollo normal activation of the embryonic genome, are excellent candidates to be embryonic miRNAs expressed as part of the lower of the embryonic genome expression, and which may be necessary to activate the rest of the genome at the 8-cell stage embryo, similar to what mir430 do in Zebrafish(44).

\section{CONCLUSIONS}

After fertilization, the transcription process is inactive, so the single protein sustenance for the zygote is given by the transcripts and proteins from the oocyte. In other words, in the beginning of the process, the success of embryonic development absolutely depends on oocyte quality. This quality is related to the effect of maternal mRNA expression, same that when translation take place, trigger the mechanisms to lead activation of the embryonic genome. Without the action of the maternal proteins, the genome of the embryo simply is not activated. This is evident in the mouse model, where blocking expression of maternal mRNA shows clearly that embryonic development is stopped in the early stages. This makes it necessary to study the way in which these maternal mRNA are expressed and translated to perform its function.

Although this knowledge is already very advanced in the mouse, in the bovine model just begins, few being the maternal mRNA described to date. So there is still a huge gap in the generation of knowledge which allow to understand these procedures in the bovine embryogenesis. In the bovine in vitro fertilization protocols, most of the eggs come from slaughter house, so the maternal genetic quality is very varied, which means that the procedures to mature them in vitro do not generate the expected success at the end of the process. To clarify what is the genetic quality that must have an egg to be deemed competent, will promote the development of a blastocyst. However, with today's technology it is still impossible to analyze the egg genome without compromising their viability. However, given that 
hasta el estadio de 8 células, después de aquí el crecimiento era detenido(150).

En lo que respecta a la acción de los RNAs pequeños, al igual que Tang et a(46) en 2077, Tesfaye et al(151) encontraron un perfil diferencial de miRNAs tanto en ovocitos inmaduros como maduros, miRNAs como el miR145, miR-292-3p y el miR-496 muestran un aumento significativo de expresión en ovocitos maduros lo que implica que estos miRNAs puedan estar involucrados en el proceso de competencia de ovocitos bovinos. Dentro los miRNAs que Tesfaye et al(151) encontraron, destacan aquéllos que estando presentes ya desde el ovocito maduro después de la fertilización; permanecen presentes hasta estadios previos a la activación del genoma embrionario; dentro de estos se encuentran el miR-145, miR-208, miR-207 y miR-125a. Aunado a lo anterior, Abd El Naby et a(152) identificaron que los miR-205, miR-150, miR-96, miR-122, miR-146a y miR-146b-5p se expresan de forma constante en el ovocito bovino y su expresión empieza a caer después de $8 \mathrm{~h}$ de maduración in vitro de los ovocitos, pero permanecen después de la fertilización hasta los estadios de 4 células, donde empiezan a decaer abruptamente en el estadio de 8 células. En concordancia con esto, Miles et a/(153) demostraron que los miR-let7b, miR-let7i y miR106a se expresan de forma específica durante el proceso de maduración de ovocitos bovinos. El patrón de expresión de estos miRNAs involucra su origen materno al igual que lo describió Tang et a/(46) para el ratón. Interesantemente Mondou et al(141), encuentra que los miR-21 y miR-130 tienen poca expresión en ovocitos inmaduros y maduros, lo que cambia de forma significativa después de la fertilización, donde se observa que aumenta su expresión a partir del estadio de dos células, manteniéndose elevada hasta la etapa de 8 células para deprimirse en el estadio de blastocisto.

Teniendo el antecedente de que los miRNAs no son activos durante la maduración de ovocitos, ni tampoco son esenciales en el desarrollo the maternal mRNA are present at the beginning of the embryonic stage, it is interesting to propose strategies, enabling to analyze the embryo quality on the basis of the expression of these transcripts, in the early stages prior to the activation of the genome. This will allow to choose only those embryos that continue their development to blastocyst, to express adequately the maternal mRNA in vitro, so that the success of the process is ensured.

\section{ACKNOWLEDGMENTS}

To PROMEP-SEP-Mexico by support OF-09-415 provided.

End of english version

embrionario, si no que los necesarios son los que se activan como parte de la activación del genoma embrionario, los miR-21 y miR-130 son excelentes candidatos para ser miRNAs embrionarios expresados como parte de la expresión menor del genoma embrionario, y que tal vez sean necesarios para activar el resto del genoma embrionario en la etapa de 8 células, al igual que lo hace mir-430 en Zebrafish(44).

\section{CONCLUSIONES}

Después de la fertilización, el proceso de transcripción es inactivo, razón por la cual el único sustento proteico que tiene el cigoto es el que le aportan los transcritos y proteínas provenientes del ovocito. En otras palabras, en un inicio el éxito del desarrollo embrionario depende absolutamente de la calidad de ovocito. Esta calidad está relacionada con el efecto de la expresión de RNAm maternos, mismos que al traducirse permiten que se activen los mecanismos necesarios que dan paso a la activación del genoma embrionario. Sin la acción 
de las proteínas maternas, simplemente no se activa el genoma del embrión. Esto ha quedado muy evidenciado en el modelo de ratón, donde al bloquear la expresión de RNAm maternos se observa claramente que el desarrollo embrionario se detiene en los primeros estadios. Esto hace que sea necesario estudiar la forma en que estos RNAm maternos se expresan y traducen para ejercer su función.

Aunque este conocimiento ya está muy avanzado en el modelo murino, en el bovino apenas comienza, siendo pocos los RNAm maternos descritos a la fecha. Así que aun existe un enorme vacío en la generación de conocimiento que permita entender estos procedimientos en la embriogénesis bovina. En los protocolos de fertilización in vitro bovinos, la mayor parte de los ovocitos provienen del rastro, por lo que la calidad genética materna es muy variada, lo que implica que los protocolos para madurarlos in vitro no generen el éxito esperado al término del proceso. Esclarecer cuál es la calidad genética que debe tener un ovocito para considerarse competente, permitirá favorecer el desarrollo de un blastocisto. Sin embargo, con la tecnología actual aún es imposible analizar el genoma de un ovocito sin comprometer su viabilidad. No obstante, dado que los RNAm maternos están presentes al inicio de la etapa embrionaria, resulta interesante proponer estrategias, que permitan analizar la calidad del embrión en base a la expresión de estos transcritos, en los estadios tempranos previos a la activación del genoma. Esto permitirá elegir in vitro sólo aquellos embriones que expresen de forma adecuada los RNAm maternos, para que continúen su desarrollo embrionario hasta blastocisto, de forma tal que el éxito del proceso sea asegurado.

\section{AGRADECIMIENTOS}

Al PROMEP-SEP-México por el apoyo otorgado OF-09-415.

\section{LITERATURA CITADA}

1. Galli C, Lazzari G. The manipulation of gametes and embryos in farm animals. Reprod Domest Anim 2008;43(Suppl 2):1-7.

2. Alminana $C$, Fazeli A. Exploring the application of highthroughput genomics technologies in the field of maternalembryo communication. Theriogenology 2012;77:717-737.

3. Hall V, Hinrichs K, Lazzari G, Betts DH, Hyttel P. Early embryonic development, assisted reproductive technologies, and pluripotent stem cell biology in domestic mammals. Vet ] 2013;197:128-142.

4. Rodriguez $\mathrm{KF}$, Farin $\mathrm{CE}$. Gene transcription and regulation of oocyte maturation. Reprod Fertil Dev 2004;16:55-67.

5. Canipari R. Oocyte-granulosa cell interactions. Hum Reprod Update 2000;6:279-289.

6. Nivet $A L$, Bunel $A$, Labrecque $R$, Belanger J, Vigneault $C$, Blondin $P$, Sirard MA. FSH withdrawal improves developmental competence of oocytes in the bovine model. Reproduction 2012;143:165-171.

7. Fujita T, Umeki H, Shimura H, Kugumiya K, Shiga K. Effect of group culture and embryo-culture conditioned medium on development of bovine embryos. J Reprod Dev 2006;52:137-142.

8. Salvador I, Cebrian-Serrano A, Salamone D, Silvestre MA. Effect of number of oocytes and embryos on in vitro oocyte maturation, fertilization and embryo development in bovine. Spanish J Agric Res 2011;9:744-752.

9. Herradón PG, Quintela LA, Becerra JJ, Ruidal S, Fernández $M$. Fecundación in vitro: alternativa para la mejora genética en bovinos. Arch Latinoam Prod Anim 2007;15:33-39.

10. Li L, Baibakov B, Dean J. A subcortical maternal complex essential for preimplantation mouse embryogenesis. Dev Cell 2008;15:416-425.

11. Li L, Zheng $P$, Dean J. Maternal control of early mouse development. Development 2010;137:859-870.

12. Sirard MA. Factors affecting oocyte and embryo transcriptomes. Reprod Domest Anim 2012;47(Suppl 4):148155.

13. Kanka J, Kepkova K, Nemcova L. Gene expression during minor genome activation in preimplantation bovine development. Theriogenology 2009;72:572-583.

14. Barckmann B, Simonelig M. Control of maternal mRNA stability in germ cells and early embryos. Biochim Biophys Acta 2013;1829:714-724.

15. Vanderhyden B. Molecular basis of ovarian development and function. Front Biosci 2002;7:2006-2022.

16. Soto-Suazo M, San Martin S, Zorn TM. Collagen and tenascin-C expression along the migration pathway of mouse primordial germ cells. Histochem Cell Biol 2004;121:149153.

17. Palma $G A$, Arganaraz $M E$, Barrera $A D$, Rodler $D$, Mutto $A A$, Sinowatz F. Biology and biotechnology of follicle development. Sci World J 2012; doi:10.1100/2012/938138.

18. Zheng P, Dean J. Oocyte-specific genes affect folliculogenesis, fertilization, and early development. Semin Reprod Med 2007; 25:243-251.

19. Valdez KE, Cuneo SP, Turzillo AM. Regulation of apoptosis in the atresia of dominant bovine follicles of the first follicular wave following ovulation. Reproduction 2005;130:71-81. 


\section{Eduviges Burrola-Barraza, et al. / Rev Mex Cienc Pecu 2015;6(1):39-68}

20. Antczak M, Van Blerkom J. Oocyte influences on early development: the regulatory proteins leptin and STAT3 are polarized in mouse and human oocytes and differentially distributed within the cells of the preimplantation stage embryo. Mol Hum Reprod 1997;3:1067-1086.

21. Wassarman PM, Litscher ES. Mammalian fertilization: the egg's multifunctional zona pellucida. Int J Dev Biol 2008;52:665-676.

22. Huang HF, He RH, Sun CC, Zhang $Y$, Meng QX, Ma YY. Function of aquaporins in female and male reproductive systems. Hum Reprod Update 2006;12:785-795.

23. Diaz FJ, Wigglesworth K, Eppig JJ. Oocytes determine cumulus cell lineage in mouse ovarian follicles. J Cell Sci 2007; 120:1330-1340.

24. Hennet $M L$, Combelles CM. The antral follicle: a microenvironment for oocyte differentiation. Int J Dev Biol 2012;56:819-831.

25. Bettegowda A, Lee KB, Smith GW. Cytoplasmic and nuclear determinants of the maternal-to-embryonic transition. Reprod Fertil Dev 2008;20:45-53.

26. De La Fuente R, Eppig JJ. Transcriptional activity of the mouse oocyte genome: companion granulosa cells modulate transcription and chromatin remodeling. Dev Biol 2001;229:224-236.

27. Chicoine J, Benoit $P$, Gamberi $C$, Paliouras M, Simonelig M, Lasko P. Bicaudal-C recruits CCR4-NOT deadenylase to target mRNAs and regulates oogenesis, cytoskeletal organization, and its own expression. Dev Cell 2007;13:691-704.

28. Benoit P, Papin C, Kwak JE, Wickens M, Simonelig M. PAPand GLD-2-type poly(A) polymerases are required sequentially in cytoplasmic polyadenylation and oogenesis in Drosophila. Development 2008;135:1969-1979.

29. Kim JH, Richter JD. Opposing polymerase-deadenylase activities regulate cytoplasmic polyadenylation. Mol Cell 2006;24:173-183.

30. Belloc E, Mendez R. A deadenylation negative feedback mechanism governs meiotic metaphase arrest. Nature 2008;452:1017-1021.

31. Guzeloglu-Kayisli O, Lalioti MD, Aydiner F, Sasson I, Ilbay $\mathrm{O}$, Sakkas $\mathrm{D}$, et al. Embryonic poly(A)-binding protein (EPAB) is required for oocyte maturation and female fertility in mice. Biochem J 2012;446:47-58.

32. Barnard DC, Cao Q, Richter JD. Differential phosphorylation controls Maskin association with eukaryotic translation initiation factor 4E and localization on the mitotic apparatus. Mol Cell Biol 2005;25:7605-7615.

33. Su YQ, Sugiura K, Woo $Y$, Wigglesworth K, Kamdar $S$, Affourtit J, Eppig J]. Selective degradation of transcripts during meiotic maturation of mouse oocytes. Dev Biol 2007;302:104-117.

34. Tomek W, Wollenhaupt K. The "closed loop model" in controlling mRNA translation during development. Anim Reprod Sci 2012;134:2-8.

35. Ellederova $Z$, Cais O, Susor A, Uhlirova K, Kovarova $H$, Jelinkova $L$, Tomek $W$, Kubelka M. ERK1/2 map kinase metabolic pathway is responsible for phosphorylation of translation initiation factor eIF4E during in vitro maturation of pig oocytes. Mol Reprod Dev 2008;75:309-317.

36. Tomek W, Melo Sterza FA, Kubelka M, Wollenhaupt K, Torner $\mathrm{H}$, Anger $M$, Kanitz W. Regulation of translation during in vitro maturation of bovine oocytes: the role of MAP kinase,
eIF4E (cap binding protein) phosphorylation, and eIF4EBP1. Biol Reprod 2002;66:1274-1282.

37. Bachvarova R, De Leon V, Johnson A, Kaplan G, Paynton BV. Changes in total RNA, polyadenylated RNA, and actin mRNA during meiotic maturation of mouse oocytes. Dev Biol 1985;108:325-331.

38. Vassalli JD, Huarte J, Belin D, Gubler P, Vassalli A, O'Connell $\mathrm{ML}$, et al. Regulated polyadenylation controls mRNA translation during meiotic maturation of mouse oocytes. Genes Dev 1989;3:2163-2171.

39. McGrew LL, Richter JD. Xenopus oocyte poly(A) RNAs that hybridize to a cloned interspersed repeat sequence are not translatable. Dev Biol 1989;134:267-270.

40. Paris J, Swenson K, Piwnica-Worms H, Richter JD. Maturation-specific polyadenylation: in vitro activation by p34cdc2 and phosphorylation of a 58-kD CPE-binding protein. Genes Dev 1991;5:1697-1708.

41. Mendez R, Richter JD. Translational control by CPEB: a means to the end. Nat Rev Mol Cell Biol 2001;2:521-529.

42. Seli E, Lalioti MD, Flaherty SM, Sakkas D, Terzi N, Steitz JA. An embryonic poly(A)-binding protein (ePAB) is expressed in mouse oocytes and early preimplantation embryos. Proc Natl Acad Sci 2005;102:367-372.

43. Suh $N$ Blelloch $R$. Small RNAs in early mammalian development: from gametes to gastrulation. Development 2011;138:1653-1661.

44. Giraldez AJ, Mishima Y, Rihel J, Grocock RJ, Van Dongen S, Inoue $\mathrm{K}$, et al. Zebrafish MiR-430 promotes deadenylation and clearance of maternal mRNAs. Science 2006;312:7579.

45. Wei C, Salichos L, Wittgrove CM, Rokas A, Patton JG. Transcriptome-wide analysis of small RNA expression in early zebrafish development. RNA 2012;18:915-929.

46. Tang F, Kaneda M, O'Carroll D, Hajkova P, Barton SC, Sun $Y A$, et al. Maternal microRNAs are essential for mouse zygotic development. Genes Dev 2007;21:644-648.

47. Ma J, Flemr M, Stein P, Berninger $P$, Malik R, Zavolan $M$, Svoboda P , Schultz RM. MicroRNA activity is suppressed in mouse oocytes. Curr Biol 2010;20:265-270.

48. Wang $X$, Gu Z, Jiang $H$. MicroRNAs in farm animals. Animal 2013;7:1567-1575.

49. Hossain MM, Salilew-Wondim D, Schellander K, Tesfaye D. The role of microRNAs in mammalian oocytes and embryos. Anim Reprod Sci 2012;134:36-44.

50. Westholm JO, Lai EC. Mirtrons: microRNA biogenesis via splicing. Biochimie 2011;93:1897-1904.

51. Bushati N, Cohen SM. MicroRNA functions. Annu Rev Cell Dev Biol 2007;23:175-205.

52. Suh N, Baehner L, Moltzahn F, Melton C, Shenoy A, Chen J , Blelloch R. MicroRNA function is globally suppressed in mouse oocytes and early embryos. Curr Biol 2010;20:271277.

53. Curtis HJ, Sibley CR, Wood MJA. Mirtrons, an emerging class of atypical miRNA. Wiley Interdiscip. Rev.-RNA 2012;3:617-632.

54. Svoboda P, Flemr M. The role of miRNAs and endogenous siRNAs in maternal-to-zygotic reprogramming and the establishment of pluripotency. EMBO Rep 2010;11:590-597. 
55. Filipowicz W, Bhattacharyya SN, Sonenberg N. Mechanisms of post-transcriptional regulation by microRNAs: are the answers in sight? Nat Rev Genet 2008;9:102-114.

56. Tam $\mathrm{OH}$, Aravin AA, Stein P, Girard A, Murchison EP, Cheloufi $\mathrm{S}$, et al. Pseudogene-derived small interfering RNAs regulate gene expression in mouse oocytes. Nature 2008;453:534538.

57. Sijen T, Plasterk RH. Transposon silencing in the Caenorhabditis elegans germ line by natural RNAi. Nature 2003;426:310-314.

58. Peaston $A E$, Evsikov $A V$, Graber $\mathrm{JH}$, de Vries WN, Holbrook $A E$, Solter $D$, Knowles BB. Retrotransposons regulate host genes in mouse oocytes and preimplantation embryos. Dev Cell 2004;7:597-606.

59. Watanabe $T$, Totoki $Y$, Toyoda A, Kaneda M, KuramochiMiyagawa S, Obata $Y$, et al. Endogenous siRNAs from naturally formed dsRNAs regulate transcripts in mouse oocytes. Nature 2008;453:539-543.

60. Murchison EP, Stein P, Xuan Z, Pan H, Zhang MQ, Schultz RM, Hannon GJ. Critical roles for Dicer in the female germline. Genes Dev 2007;21:682-693.

61. Svoboda P. Why mouse oocytes and early embryos ignore miRNAs? RNA Biol 2013;7:559-563.

62. Saunders CM, Larman MG, Parrington J, Cox LJ, Royse J, Blayney LM, et al. PLC zeta: a sperm-specific trigger of $\mathrm{Ca}(2+)$ oscillations in eggs and embryo development. Development 2002;129:3533-3544.

63. Ziomek $\mathrm{CA}$, Johnson $\mathrm{MH}$. Cell surface interaction induces polarization of mouse 8-cell blastomeres at compaction. Cell 1980;21:935-942.

64. Tarkowski AK, Wroblewska J. Development of blastomeres of mouse eggs isolated at the 4- and 8-cell stage. J Embryol Exp Morphol 1967;18:155-180.

65. Johnson $\mathrm{MH}$, Ziomek CA. The foundation of two distinct cell lineages within the mouse morula. Cell 1981;24:71-80.

66. Matzuk MM, Burns KH. Genetics of mammalian reproduction: modeling the end of the germline. Annu Rev Physiol 2012;74:503-528.

67. Russo GL, Wilding M, Marino M, Dale B. Ins and outs of meiosis in ascidians. Semin Cell Dev Biol 1998;9:559-567.

68. Santos F, Dean W. Epigenetic reprogramming during early development in mammals. Reproduction 2004;127:643-651.

69. Weaver JR, Susiarjo M, Bartolomei MS. Imprinting and epigenetic changes in the early embryo. Mamm Genome 2009;20:532-543.

70. Mancini-Dinardo D, Steele SJ, Levorse JM, Ingram RS, Tilghman SM. Elongation of the Kcnq1ot1 transcript is required for genomic imprinting of neighboring genes. Genes Dev 2006;20:1268-1282.

71. Fitzpatrick GV, Soloway PD, Higgins MJ. Regional loss of imprinting and growth deficiency in mice with a targeted deletion of KvDMR1. Nat Genet 2002;32:426-431.

72. Ooi SL, Henikoff S. Germline histone dynamics and epigenetics. Curr Opin Cell Biol 2007;19:257-265.

73. Kaneda M, Okano M, Hata K, Sado T, Tsujimoto N, Li E, Sasaki $\mathrm{H}$. Essential role for de novo DNA methyltransferase Dnmt3a in paternal and maternal imprinting. Nature 2004;429:900-903.
74. Reik W, Dean W, Walter J. Epigenetic reprogramming in mammalian development. Science 2001;293:1089-1093.

75. Derijck AA, van der Heijden GW, Giele M, Philippens ME, van Bavel CC, de Boer P. GammaH2AX signalling during sperm chromatin remodelling in the mouse zygote. DNA Repair (Amst) 2006;5:959-971.

76. Adenot PG, Mercier Y, Renard JP, Thompson EM. Differential $\mathrm{H} 4$ acetylation of paternal and maternal chromatin precedes DNA replication and differential transcriptional activity in pronuclei of 1-cell mouse embryos. Development 1997; 124:4615-4625.

77. Santos F, Hendrich B, Reik W, Dean W. Dynamic reprogramming of DNA methylation in the early mouse embryo. Dev Biol 2002;241:172-182.

78. Roest HP, Baarends WM, de Wit J, van Klaveren JW, Wassenaar E, Hoogerbrugge JW, van Cappellen WA, et al. The ubiquitin-conjugating DNA repair enzyme HR6A is a maternal factor essential for early embryonic development in mice. Mol Cell Biol 2004;24:5485-5495.

79. Philpott A, Leno GH, Laskey RA. Sperm decondensation in Xenopus egg cytoplasm is mediated by nucleoplasmin. Cell 1991;65:569-578.

80. Burns $\mathrm{KH}$, Viveiros $M M$, Ren $\mathrm{Y}$, Wang $\mathrm{P}$, DeMayo FJ, Frail DE, Eppig JJ , Matzuk MM. Roles of NPM2 in chromatin and nucleolar organization in oocytes and embryos. Science 2003;300:633-636.

81. Sanz LA, Kota SK, Feil R. Genome-wide DNA demethylation in mammals. Genome Biol 2010;11:110.

82. McLay DW, Clarke HJ. Remodelling the paternal chromatin at fertilization in mammals. Reproduction 2003;125:625633.

83. Lee $\mathrm{J}$, Inoue $\mathrm{K}$, Ono $\mathrm{R}$, Ogonuki $\mathrm{N}$, Kohda $\mathrm{T}$, KanekoIshino $T$, Ogura A, Ishino $F$. Erasing genomic imprinting memory in mouse clone embryos produced from day 11.5 primordial germ cells. Development 2002;129:1807-1817.

84. Oswald J, Engemann S, Lane N, Mayer W, Olek A, Fundele R, Dean W, Reik W , Walter J. Active demethylation of the paternal genome in the mouse zygote. Curr Biol 2000;10:475-478.

85. Bourc'his D, Le Bourhis D, Patin D, Niveleau A, Comizzoli $\mathrm{P}$, Renard JP, Viegas-Pequignot E. Delayed and incomplete reprogramming of chromosome methylation patterns in bovine cloned embryos. Curr Biol 2001;11:1542-1546.

86. Dean W, Santos F, Reik W. Epigenetic reprogramming in early mammalian development and following somatic nuclear transfer. Semin Cell Dev Biol 2003;14:93-100.

87. Kang YK, Park JS, Koo DB, Choi YH, Kim SU, Lee KK, Han YM. Limited demethylation leaves mosaic-type methylation states in cloned bovine pre-implantation embryos. EMBO J 2002;21:1092-1100.

88. Wossidlo M, Nakamura T, Lepikhov $\mathrm{K}$, Marques $\mathrm{CJ}$, Zakhartchenko V, Boiani M, et al. 5-Hydroxymethylcytosine in the mammalian zygote is linked with epigenetic reprogramming. Nat Commun 2011;2:241.

89. Gu TP, Guo F, Yang H, Wu HP, Xu GF, Liu W, et al. The role of Tet3 DNA dioxygenase in epigenetic reprogramming by oocytes. Nature 2011;477:606-610.

90. Mizuno S, Sono Y, Matsuoka T, Matsumoto K, Saeki K, Hosoi $Y$, et al. Expression and subcellular localization of 


\section{Eduviges Burrola-Barraza, et al. / Rev Mex Cienc Pecu 2015;6(1):39-68}

GSE protein in germ cells and preimplantation embryos. J Reprod Dev 2006;52:429-438.

91. Hatanaka Y, Shimizu N, Nishikawa S, Tokoro M, Shin SW, Nishihara T, et al. GSE is a maternal factor involved in active DNA demethylation in zygotes. PLoS One 2013;8:e60205.

92. Nakamura $T$, Arai $Y$, Umehara $H$, Masuhara $M$, Kimura $T$, Taniguchi $\mathrm{H}$, et al. PGC7/Stella protects against DNA demethylation in early embryogenesis. Nat Cell Biol 2007;9:64-71.

93. Nakamura $\mathrm{T}$, Liu $\mathrm{YJ}$, Nakashima $\mathrm{H}$, Umehara $\mathrm{H}$, Inoue $\mathrm{K}$ Matoba $\mathrm{S}$, et al. PGC7 binds histone H3K9me2 to protect against conversion of $5 \mathrm{mC}$ to $5 \mathrm{hmC}$ in early embryos. Nature 2012;486:415-419.

94. Saitou M, Barton SC, Surani MA. A molecular programme for the specification of germ cell fate in mice. Nature 2002;418:293-300.

95. Bortvin A, Goodheart M, Liao M, Page DC. Dppa3 / Pgc7 / stella is a maternal factor and is not required for germ cell specification in mice. BMC Dev Biol 2004;4. doi:10.1186/1471-213X-4-2.

96. Machaty Z, Peippo J, Peter A. Production and manipulation of bovine embryos: Techniques and terminology. Theriogenology 2012;78:937-950.

97. Messerschmidt DM, de Vries W, Ito M, Solter D, FergusonSmith A, Knowles BB. Trim28 is required for epigenetic stability during mouse oocyte to embryo transition. Science 2012;335:1499-1502.

98. Mayer W, Niveleau A, Walter J, Fundele R, Haaf T. Demethylation of the zygotic paternal genome. Nature 2000;403:501-502.

99. Carlson LL, Page AW, Bestor TH. Properties and localization of DNA methyltransferase in preimplantation mouse embryos: implications for genomic imprinting. Genes Dev 1992;6:2536-2541.

100. Doherty AS, Bartolomei MS, Schultz RM. Regulation of stage-specific nuclear translocation of Dnmt1o during preimplantation mouse development. Dev Biol 2002;242:255-266.

101. De La Fuente R. Chromatin modifications in the germinal vesicle (GV) of mammalian oocytes. Dev Biol 2006;292:112.

102. Braun $\mathrm{JE}$, Huntzinger $\mathrm{E}$, Izaurralde $\mathrm{E}$. A molecular link between miRISCs and deadenylases provides new insight into the mechanism of gene silencing by microRNAs. Cold Spring Harb Perspect Biol 2012;4: doi 10.1101/ cshperspect.a012328.

103. Lund E, Liu M, Hartley RS, Sheets MD, Dahlberg JE. Deadenylation of maternal mRNAs mediated by miR-427 in Xenopus laevis embryos. RNA 2009;15:2351-2363.

104. Lingenfelter BM, Tripurani SK, Tejomurtula J, Smith GW , Yao J. Molecular cloning and expression of bovine nucleoplasmin 2 (NPM2): a maternal effect gene regulated by miR-181a. Reprod Biol Endocrinol 2011;9:40. doi:10.1186/1477-7827-9-40.

105. Tripurani SK, Lee KB, Wee G, Smith GW, Yao J. MicroRNA196 a regulates bovine newborn ovary homeobox gene (NOBOX) expression during early embryogenesis. BMC Dev Biol 2011;11:25.
106. Svoboda P. Why mouse oocytes and early embryos ignore miRNAs? RNA Biol 2010;7:559-563.

107. Clapier CR, Cairns BR. The biology of chromatin remodeling complexes. Annu Rev Biochem 2009;78:273-304.

108. Bultman SJ, Gebuhr TC, Pan H, Svoboda P, Schultz RM, Magnuson T. Maternal BRG1 regulates zygotic genome activation in the mouse. Genes Dev 2006;20:1744-1754.

109. Metchat A, Akerfelt M, Bierkamp C, Delsinne V, Sistonen $\mathrm{L}$, Alexandre H, Christians ES. Mammalian heat shock factor 1 is essential for oocyte meiosis and directly regulates Hsp90alpha expression. J Biol Chem 2009;284:9521-9528.

110. Christians E, Davis AA, Thomas SD, Benjamin IJ. Maternal effect of Hsf1 on reproductive success. Nature 2000;407:693-694.

111. Ma J, Zeng F, Schultz RM, Tseng H. Basonuclin: a novel mammalian maternal-effect gene. Development 2006;133:2053-2062.

112. Wang QT, Piotrowska K, Ciemerych MA, Milenkovic L, Scott MP, Davis RW, Zernicka-Goetz M. A genome-wide study of gene activity reveals developmental signaling pathways in the preimplantation mouse embryo. Dev Cell 2004;6:133144.

113. Foygel $\mathrm{K}$, Choi $\mathrm{B}$, Jun $\mathrm{S}$, Leong $\mathrm{DE}$, Lee $\mathrm{A}$, Wong $\mathrm{CC}$, et al. A novel and critical role for Oct4 as a regulator of the maternal-embryonic transition. PLoS One 2008;3:e4109.

114. Palmieri $\mathrm{SL}$, Peter $\mathrm{W}$, Hess $\mathrm{H}$, Scholer HR. Oct-4 transcription factor is differentially expressed in the mouse embryo during establishment of the first two extraembryonic cell lineages involved in implantation. Dev Biol 1994;166:259-267.

115. Nichols J, Zevnik B, Anastassiadis K, Niwa H, KleweNebenius D, Chambers I, Scholer H, Smith A. Formation of pluripotent stem cells in the mammalian embryo depends on the POU transcription factor Oct4. Cell 1998;95:379391.

116. Avilion AA, Nicolis SK, Pevny LH, Perez L, Vivian N , Lovell-Badge R. Multipotent cell lineages in early mouse development depend on SOX2 function. Genes Dev 2003;17:126-140.

117. Lykke-Andersen K, Gilchrist MJ, Grabarek JB, Das P, Miska $\mathrm{E}$, Zernicka-Goetz M. Maternal Argonaute 2 is essential for early mouse development at the maternal-zygotic transition. Mol Biol Cell 2008;19:4383-4392.

118. Ramos SB, Stumpo DJ, Kennington EA, Phillips RS, Bock $\mathrm{CB}$, Ribeiro-Neto F, Blackshear PJ. The $\mathrm{CCCH}$ tandem zincfinger protein Zfp36l2 is crucial for female fertility and early embryonic development. Development 2004;131:4883-4893.

119. Tsukamoto S, Kuma A, Murakami M, Kishi C, Yamamoto A , Mizushima N. Autophagy is essential for preimplantation development of mouse embryos. Science 2008;321:117120.

120. Xu YN, Shen XH, Lee SE, Kwon JS, Kim DJ, Heo YT, Cui $\mathrm{XS}, \mathrm{Kim} \mathrm{NH}$. Autophagy influences maternal mRNA degradation and apoptosis in porcine parthenotes developing in vitro. J Reprod Dev 2012;58:576-584.

121. Flach G, Johnson MH, Braude PR, Taylor RA, Bolton VN. The transition from maternal to embryonic control in the 2-cell mouse embryo. EMBO J 1982;1:681-686. 
122. Howlett SK, Bolton VN. Sequence and regulation of morphological and molecular events during the first cell cycle of mouse embryogenesis. J Embryol Exp Morphol 1985;87:175-206.

123. Telford NA, Watson AJ, Schultz GA. Transition from maternal to embryonic control in early mammalian development: a comparison of several species. Mol Reprod Dev 1990;26:90-100.

124. Schultz RM. Regulation of zygotic gene activation in the mouse. Bioessays 1993;15:531-538.

125. Newport J, Kirschner M. A major developmental transition in early Xenopus embryos: I. characterization and timing of cellular changes at the midblastula stage. Cell 1982;30:675-686.

126. Brevini TA, Cillo F, Colleoni S, Lazzari G, Galli C, Gandolfi F. Expression pattern of the maternal factor zygote arrest 1 (Zar1) in bovine tissues, oocytes, and embryos. Mol Reprod Dev 2004;69:375-380.

127. Pennetier S, Uzbekova S, Perreau C, Papillier P, Mermillod $\mathrm{P}$, Dalbies-Tran R. Spatio-temporal expression of the germ cell marker genes MATER, ZAR1, GDF9, BMP15, and VASA in adult bovine tissues, oocytes, and preimplantation embryos. Biol Reprod 2004;71:1359-1366.

128. Uzbekova S, Roy-Sabau M, Dalbies-Tran R, Perreau C, Papillier $\mathrm{P}$, Mompart $\mathrm{F}$, et al. Zygote arrest 1 gene in pig, cattle and human: evidence of different transcript variants in male and female germ cells. Reprod Biol Endocrinol 2006;4:12. doi:10.1186/1477-7827-4-12.

129. Wu X, Viveiros MM, Eppig JJ, Bai Y, Fitzpatrick SL, Matzuk MM. Zygote arrest 1 (Zar1) is a novel maternal-effect gene critical for the oocyte-to-embryo transition. Nat Genet 2003;33:187-191.

130. Wu X, Wang $P$, Brown CA, Zilinski CA, Matzuk MM. Zygote arrest 1 (Zar1) is an evolutionarily conserved gene expressed in vertebrate ovaries. Biol Reprod 2003;69:861867.

131. Tong ZB, Gold L, Pfeifer KE, Dorward $H$, Lee $E$, Bondy CA, Dean J , Nelson LM. Mater, a maternal effect gene required for early embryonic development in mice. Nat Genet 2000;26:267-268.

132. Ohsugi M, Zheng P, Baibakov B, Li L, Dean J. Maternally derived FILIA-MATER complex localizes asymmetrically in cleavage-stage mouse embryos. Development 2008;135:259-269.

133. Yurttas P, Vitale AM, Fitzhenry RJ, Cohen-Gould L, Wu W, Gossen JA, Coonrod SA. Role for PADI6 and the cytoplasmic lattices in ribosomal storage in oocytes and translational control in the early mouse embryo. Development 2008;135:2627-2636.

134. Esposito G, Vitale AM, Leijten FP, Strik AM, Koonen-Reemst AM, Yurttas $P$, et al. Peptidylarginine deiminase (PAD) 6 is essential for oocyte cytoskeletal sheet formation and female fertility. Mol Cell Endocrinol 2007;273:25-31.

135. Zheng $P$, Dean J. Role of Filia, a maternal effect gene, in maintaining euploidy during cleavage-stage mouse embryogenesis. Proc Natl Acad Sci 2009;106:7473-7478.

136. Fair $T$, Hyttel $P$, Greve $T$. Bovine oocyte diameter in relation to maturational competence and transcriptional activity. Mol Reprod Develop 1995;42:437-442.
137. Biase FH, Fonseca Merighe GK, Santos Biase WK, Martelli $\mathrm{L}$, Meirelles FV. Global poly $(\mathrm{A})$ mRNA expression profile measured in individual bovine oocytes and cleavage embryos. Zygote 2008;16:29-38.

138. Fair T, Carter F, Park S, Evans AC, Lonergan P. Global gene expression analysis during bovine oocyte in vitro maturation. Theriogenology 2007;68(Suppl 1):S91-97.

139. Brevini TA, Cillo F, Antonini S, Tosetti V, Gandolfi F. Temporal and spatial control of gene expression in early embryos of farm animals. Reprod Fertil Dev 2007;19:35-42.

140. Burrola-Barraza ME, Hernandez-Seanez R, Barcelo-Fimbres M, Rodriguez-Almeida FA, Gonzalez-Rodriguez E, GarciaQuinonez S, et al. Dicer gene expression during early bovine embryo development. Mol Reprod Dev 2011;78:622.

141. Mondou E, Dufort I, Gohin M, Fournier E, Sirard MA. Analysis of microRNAs and their precursors in bovine early embryonic development. Mol Hum Reprod 2012;18:425434.

142. Pennetier S, Perreau C, Uzbekova S, Thelie A, Delaleu B, Mermillod $P$, Dalbies-Tran R. MATER protein expression and intracellular localization throughout folliculogenesis and preimplantation embryo development in the bovine. BMC Dev Biol 2006;6:26.

143. Leonhardt $\mathrm{H}$, Page AW, Weier HU, Bestor TH. A targeting sequence directs DNA methyltransferase to sites of DNA replication in mammalian nuclei. Cell 1992;71:865-873.

144. Ma J, Cao X. Regulation of Stat3 nuclear import by importin alpha5 and importin alpha7 via two different functional sequence elements. Cell Signal 2006;18:1117-1126.

145. Tejomurtula J, Lee KB, Tripurani SK, Smith GW, Yao J. Role of importin alpha8, a new member of the importin alpha family of nuclear transport proteins, in early embryonic development in cattle. Biol Reprod 2009;81:333342.

146. Bettegowda A, Yao J, Sen A, Li Q, Lee KB, Kobayashi Y, et al. JY-1, an oocyte-specific gene, regulates granulosa cell function and early embryonic development in cattle. Proc Natl Acad Sci 2007;104:17602-17607.

147. de Camargo G, Baldi F, Regitano L, Tonhati H. Characterization of the exonic regions of the JY-1 gene in Zebu cattle and buffaloes. Reprod Domest Anim 2013;48:918-922.

148. Suzumori N, Yan C, Matzuk MM, Rajkovic A. Nobox is a homeobox-encoding gene preferentially expressed in primordial and growing oocytes. Mech Dev 2002;111:137141.

149. Tripurani SK, Lee KB, Wang L, Wee G, Smith GW, Lee YS, Latham KE, Yao J. A novel functional role for the oocytespecific transcription factor newborn ovary homeobox (NOBOX) during early embryonic development in cattle. Endocrinology 2011;152:1013-1023.

150. Golding MC, Williamson GL, Stroud TK, Westhusin ME, Long CR. Examination of DNA methyltransferase expression in cloned embryos reveals an essential role for Dnmt1 in bovine development. Mol Reprod Develop 2011;78:306317. 
M. Eduviges Burrola-Barraza, et al. / Rev Mex Cienc Pecu 2015;6(1):39-68

151. Tesfaye D, Worku D, Rings F, Phatsara C, Tholen E, Schellander $\mathrm{K}$, Hoelker M. Identification and expression profiling of microRNAs during bovine oocyte maturation using heterologous approach. Mol Reprod Develop 2009;76:665-677.

152. Abd El Naby WS, Hagos TH, Hossain MM, Salilew-Wondim $D$, Gad AY, Rings F, et al. Expression analysis of regulatory
microRNAs in bovine cumulus oocyte complex and preimplantation embryos. Zygote 2011;21:31-51.

153. Miles JR, McDaneld TG, Wiedmann RT, Cushman RA, Echternkamp SE, Vallet JL, Smith TPL. MicroRNA expression profile in bovine cumulus-oocyte complexes: Possible role of let-7 and miR-106a in the development of bovine oocytes. Anim Reprod Sci 2012;130:16-26. 